\title{
Öğretmenlerin Sendikal Örgütlenmeye Yönelik Görüşlerinin İncelenmesi
}

\author{
Dr. Öğr. Üyesi Rafet AYDIN \\ Mehmet Akif Ersoy Üniversitesi, Eğitim Fakültesi, Eğitim Bilimleri Bölümü, Burdur / Türkiye \\ raydin@mehmetakif.edu.tr, ORCID: 0000-0002-7613-3198
}

\section{Mesut SOYDAN}

Isparta İl Milli Eğitim Müdürlüğü, Isparta / Türkiye mesutsoydan@hotmail.com, ORCID: 0000 0002-7950-6949

\section{$\ddot{\mathbf{O} z}$}

Öğretmenlerin birçok görev ve sorumluluklarının yanında sorunları da bulunmaktadır. Bu sorunlar genel olarak; öğretmenlerin yetiştirilmesi/yetişmesi, ekonomik sorunlar, hukuki ve toplumsal statü sorunlar, örgütlenme (sendikalaşma) sorunları, sayısal dağılım ve meslekî yayın sorunları şeklinde sıralanabilir. Bu sorunlardan biri olan sendikalaşma hususu araştırmanın temel konusudur. Araştırmanın amacı ise öğretmenlerin meslekî örgütlenme (sendikalaşma) ile ilgili görüşlerinin incelenmesi meselesidir. $\mathrm{Bu}$ amaca ulaşabilmek için öğretmenlerin sendikalara üye olup olmama nedenleri ve meslekî örgütlenme ile ilgili görüşleri cinsiyet, kıdem, branş ve eğitim durumları değişkenleri çerçevesinde incelenmiştir. Araştırmada genel tarama modellerinden olan ilişkisel tarama modeli kullanılmıştır. Araştırmanın nicel boyutunun verileri “Sınıf Öğretmenleri ve Yöneticilerinin Meslekî Örgütlenme Tutumları Ölçeği” ile toplanmıştır. Öğretmenlerin sendika değişikliği yapma veya yapmama nedenlerine ilişkin veriler ise yarı yapılandırılmış görüşme yöntemi ile elde edilmiştir. Araştırma evrenini 2016 yılında Burdur il merkezi ve ilçelerinde görev yapan öğretmenler

* Sorumlu Yazar. Tel: +90 (533) 2493043

Makale Tarih Bilgisi. Gönderim: 13.04.2019, Kabûl: 09.02.2020, Basım: Haziran, 2021

(C) 2021. Kalem Eğitim ve Sağlık Hizmetleri Vakfi. Bütün Hakları Saklıdır. ISSN: 2146-5606, e-ISSN: 2687-6574. 
oluşturmaktadır. Çalışmanın örneklemini ise bu evrenden tabakalama örnekleme yöntemi ile seçilen 778 öğretmen oluşturmaktadır. Elde edilen nicel veriler bilgisayar paket programları kullanılarak betimsel istatistik, bağımsız örneklemler $t$ Testi ve tek yönlü varyans analizi (ANOVA) ile test edilmiştir. Yarı yapılandırılmış açık uçlu soruyla elde edilen veriler de betimsel analiz ve içerik analizi ile değerlendirilmiştir. Araştırma sonucunda sendika üyesi olmayan öğretmenlerin sendika üyesi olan öğretmenlere göre, genç öğretmenlerin ise daha kıdemli öğretmenlere göre meslekî örgütlenmeye ilişkin daha olumlu görüşe sahip oldukları ve öğretmenlerin daha çok politik sebeplerden dolayı sendika değişikliği yaptıkları ortaya çıkmıştır.

Anahtar Kelimeler: Örgütlenme; Öğretmen; Öğretmen Sendikacılığı; Sendikalaşma.

\title{
Investigation of Teachers' Views on Union Organization
}

\begin{abstract}
Teachers have problems besides many duties and responsibilities. These problems in general can be mentioned as; training/education of teachers, economic problems, legal and social status problems, organization (unionization), numerical distribution and professional publication problems. Among these problems, unionization is the subject of the research. The purpose of the research is: "Examining the views of teachers about professional organization (unionization)". To achieve this goal, the effects of teachers 'gender, seniority, branch and educational status on their views on professional organization and the reasons of teachers' membership to unions were examined. Among the general screening models, relational screening model was used in the research. The data of the quantitative dimension of the study was obtained via the "Professional Organizational Attitudes Scale of Classroom Teachers and Administrators Scale". The universe of the research consists of teachers working in Burdur city center and its districts in 2016. As a sample of the study 778 teachers selected from this universe by stratification sampling method. The quantitative data obtained were tested with descriptive statistics, independent samples t-test and one-way analysis of variance (ANOVA) using computer package programs. Data obtained with a semi-structured open-ended question; evaluated through descriptive analysis and content analysis. As a result of the research, it was revealed that; teachers who are not union members have a more positive view of organization than teachers who are union members; young teachers have a more positive view of professional organization than more senior teachers; the teachers made union changes mostly due to political reasons.
\end{abstract}

Keywords: Organization; Teacher; Teacher unionism; Unionization. 


\section{Extended Summary}

\section{Purpose}

The purpose of the research is to examine the views of teachers on professional organization and to determine whether teachers make union changes or not. In order to achieve this goal; the effects of teachers' gender, seniority, branch and educational status on their views on professional organization; and whether the teachers are members of unions, or they have changed unions are examined with their reasons.

It has been thought the examination of unionization, which is a teacher problem and determining whether teachers are members of unions, whether they change unions, the reasons for change, and the understanding of unionism makes this research important. The data obtained in the study and the results obtained were compared with other studies and the use of both quantitative and open-ended semi-structured questions in the collection of the data was considered to add importance to the research.

This research has been considered important since it is thought to examine the formation and development of education unions in Turkey and teachers' tendencies towards unionization, teachers' attitudes towards professional organization, reasons for membership of unions, factors affecting union choices and expectations from unions. It is also thought to shed light on the solution of organizational problems, which is one of the teachers' problems.

\section{The Problem of the Research}

The question: "What is the attitude of teachers towards professional organization?" posed the problem of this research. Sub-problems of the research:

1. What are the opinions of teachers against professional organization?

2. What are the positive and negative opinions of teachers against professional organization?

3. Do teachers' views on professional organization differ according to: a. Gender, b. Seniority, c. Branch, d. Educational status?

4. What are the reasons for teachers to change or not to change unions? 


\section{Limitations of the Research}

This research:

1. It has been limited to the views of teachers working in schools affiliated to the Ministry of National Education in the central and districts of Burdur province in the 2016-2017 academic year.

2. The findings obtained in the research are limited to the questions of the "Attitudes of Teachers Towards Professional Organization Scale".

\section{Method}

\section{Model of the Research}

The research was designed as a descriptive survey model. Quantitative research methods have been used in order to achieve the main purpose determined in the research. Relational screening model, which is one of the general screening models, was used in the research. The data of the quantitative dimension of the study was obtained via the "Professional Organizational Attitudes Scale of Classroom Teachers and Administrators" scale developed by Baysal, Türkmen and Yücel (2010) and semi-structured question to collect the semi-data about the reasons of teachers' decisions on union changes.

Screening models are research approaches aiming to describe a situation that exists in the past or still (Karasar, 2012). According to Balc1 (2010) descriptive research when they are made retrospectively, they reveal "what was it?". Educational research is "descriptive research" and is the first and basic research action. Many of the educational problems are descriptive.

\section{Data Collection Tools and Data Analysis}

As a data collection tool "The Professional Organizational Attitude Scale of Classroom Teachers and Administrators" consisting of 35 items developed by Baysal, Türkmen and Yücel (2010), was applied. In addition, in the research, a semi-structured open-ended question was asked and data related the reasons for teachers' change or not were obtained. The quantitative data obtained were tested with descriptive statistics, independent samples ttest and one-way analysis of variance (ANOVA) using computer package programs. Data obtained with a semi-structured open-ended question; evaluated through descriptive analysis and content analysis.

Descriptive analysis and content analysis, qualitative data obtained in the evaluation process were analyzed by dividing them into word and sentence 
units (Yıldırım and Şimşek, 2011). Coding in a general framework was used for coding the data (Strauss and Corbin, 1997, cited in Yıldırım and Şimşek, 2011). As a result of this analysis, the findings were supported by teacher views. In the scale of Baysal, Türkmen and Yücel's (2010) teachers' attitudes towards professional organization scale used in this research, the likert type questions were first consulted to learned opinion for validity and then they were subjected to factor analysis to reveal the dimensions that the questions could measure. Cronbach Alpha reliability coefficient was found to be 0.91 in the most recent version of the scale.

\section{Universe and Sampling}

The universe of the research is 3346 teachers working in Burdur city center, districts and villages in 2016. However, the sample of the study consists of 778 teachers selected from this universe by stratification sampling method. In the collection of the data, two-step simple random sampling method was used. Accordingly, in the first stage, the provincial, Bucak, Tefenni, Ağlasun, Karamanlı and Çeltikçi districts were determined with the simple random sampling method throughout the province of Burdur, and in the second stage, the institutions that will constitute up to three times. 825 of the data collection tools returned. 47 forms were excluded from evaluation due to reasons such as missing information and variables not being marked. In the last case, the views of 778 teachers, 469 from the center of Burdur, 154 from Bucak district, 42 from Tefenni, 41 from Ağlasun, 51 from Karamanlı and 21 from Çeltikçi, were evaluated.

\section{Results}

According to the analysis of the data collected quantitatively in this study, it was found that $81.7 \%$ of the teachers were members of the professional organization and $18.3 \%$ were not members of any professional organization. In this study, $89.9 \%$ of male teachers and $71.9 \%$ of female teachers are union members. In this research, it has been revealed that teachers with seniority of 6-10 years have a more positive view in the general dimension of professional organization than teachers with seniority of 26 and above. When the opinions of teachers about organization according to age groups are examined, there is no significant difference in the general dimension. It has been observed that there is no significant difference in teachers' views on organization according to their branch, type of school they work and the place they work. There was a significant difference in the opinions of teachers regarding 
the expectations from unions and teachers working in the city center seem to have a more positive attitude than teachers working in villages and towns.

According to the results obtained from the data collected with a semistructured open-ended question; when teachers' views on the reasons for changing trade unions are analyzed, it is seen that teachers make union changes mostly due to political reasons. When the reasons of teachers changing the union are examined, it is seen that the other reason is making union exchanges due to problems arising from administrators and members.

\section{Giriş}

Eğitim, kişinin zihnî, bedenî, duygusal yeteneklerinin ve toplumsal, davranışlarının en uygun şekilde ya da istenilen bir doğrultuda geliştirilmesi; kişiye birtakım amaçlara dönük yeni yetenekler, davranışlar, bilgiler kazand1rılması yolundaki çalışmaların tümüdür (Akyüz, 2012). Eğitim denilince elbette daha çok kastedilen planlı, programlı ve amaçlı eğitimdir. Amaçlar açısindan bakılınca da toplumların ekonomik, siyasal, sosyal ve ahlaki hedeflerine ancak planlı eğitimle ulaşmaları mümkündür (Aydın, 2008). Bunların yanı sıra eğitim, insanın doğumu ile başlayan ve ölümüne kadar devam eden bir süreçtir. Bu süreçte insanlara çeşitli bilgi, beceri, tutum ve değerler kazandırılmaktadır. Bu amaçlara ulaşmada öğretmenlerin yanı sıra eğitim sisteminin diğer unsurları olan eğitim programı ve öğrenci de dikkate alınmalıdır. Diğer yandan eğitimde öğrenciyi merkeze alan eğitim felsefesi akımlanı olduğu gibi öğretmeni merkeze alan felsefi yaklaşımlar da bulunmaktadır.

Alkan'a (1983) göre esasicilik akımı etrafında düşünüldüğünde eğitimde girişim, öğrenciden çok öğretmende olmalıdır. Öğrenci, öğretmenin rehberliğine ve yetişkinlerin denetimine muhtaçtır (akt; Arslanoğlu, 2018). Diğer taraftan daimicilik eğitim felsefesi akımına göre öğretmen, öğrencilerini ileri düzeyde bir entelektüel disipline teşvik etmeli ve önemsiz pratik derslerle zamanı boşa harcamamalıdır. Öğretmen, halkla ilişkiler açısından da iyi modeller geliştirmelidir. Ayrıca öğretmen, toplumsal faaliyetlere katılan ve onları gözlemleyen uzman bir gözlemci olmalıdır (Alkan, 1983'den akt; Arslanoğlu, 2018).

Bir eğitim sistemi neredeyse bütün toplumlarda genel olarak öğrenci, öğretmen ve eğitim programları üzerine kuruludur. Eğitimin etkili olabilmesi ve amaçlarını en üst düzeyde gerçekleştirebilmesi bu öğeler arasındaki uyuma bağlıdır. Bu öğelerden birisinin istenen niteliklerden yoksun olması, eğitim 
sürecini doğrudan etkilemektedir. Ancak bu üç öğeden biri olan öğretmenin, eğitimi etkileme gücünün diğer iki öğeden daha fazla olduğunu (Katkat ve Mızrak, 2003) söylemek de mümkündür. Bundan dolayıdır ki öğretmenin olmadığı bir eğitim sisteminden bahsetmek olası değildir. Öğretmenlerin öğrencilere karşı görev ve sorumlulukları olduğu gibi topluma karşıda da görev ve sorumlukları bulunmaktadır. Öğretmenlerin görev ve sorumluklarını yerine getirip getiremediklerinin bilinmesi önemlidir. Eğer öğretmenler görev ve sorumluluklarını yerine getiremiyorsa orada öğretmen sorunları vardır denilebilir. Öğretmen sorunları genel olarak yetiştirilme/yetişme sorunu, ekonomik sorunlar, hukuki problemler, toplumsal statü, sayısal dağılım ve örgütlenme meselesi olarak kategorize edilebilir. Bu kategoriler arasında bulunan öğretmenlerin örgütlenme sorunları da araştırmanın konusunu oluşturmaktadır.

Örgüt, iki veya daha fazla insanın ortak bir davranışı gerçekleştirmek için davranışlarını biçimsel kurallara göre düzenledikleri yapıdır (Keskinkılıç, 2007). Schein (1970) ise örgütü, "İ̧̧ ve iş bölümü yapılarak bir otorite ve sorumluluk hiyerarşisi içinde, ortak amaç ya da amacın gerçekleştirilmesi için bir araya gelen insanların gerçekleştirdikleri faaliyetlerinin ussal eşgüdümü’” olarak tanımlamaktadır (akt; Karataş, 2015). İnsanlar doğaları gereği toplum hâlinde yaşamak zorunda olan varlıklardır. İnsanların tüm gereksinimlerini kendi kendilerine karşılama imkânları yoktur. O hâlde insanların topluluk hâlinde yaşamalarının sonucu olarak da örgütler kurmaya ve bu örgütleri amaçları doğrultusunda yaşatmaya çalışmaları gerekmektedir (Buluç, 1997'den akt; Karataş, 2015). İnsan sosyal bir varlık olduğu için topluluk hâlinde yaşamaktadır ve dolayısıyla topluluk içerisinde de üstlendiği çeşitli sosyal rolleri bulunmaktadır. Bu bakımdan toplum içerisinde yaşama, belirli bir iş bölümünü ve örgütlülüğü zorunlu kılmaktadır. Ayrıca toplumsal gereksinimlerin ve sorunların pek çoğu, birden çok kişinin bir araya gelip güçlerini birleştirerek gereksinmeyi karşılamak ve sorunu çözmek için uğraşmayı gerektirdiğinden dolayı toplumsal eylemler artık ekonomik, politik, dinsel ve mesleksel eksenler etrafinda düzenlenmiş güçlü grupların etkileri sonucunda meydana gelmektedir (Bursalıoğlu, 1991'den akt; Karataş, 2015). Bundan ötürü bahsedilen toplumsal gereksinmeyi karşılamak ya da meslekî sorunları çözmek için bir araya gelen insanların kendi aralarında örgütlenerek iş bölümü yapmaları gerekmektedir (Baysal, Türkmen ve Yücel, 2010).

Öğretmenlik mesleği, toplum ve millet açısından önemli bir yere sahiptir. Bu önemin ilk sebebi, öğretmenin okulda kültürel mirası aktarmakta ve 
toplumun bütünlüğünün korunmasına yardımcı olmasıdır. İkinci sebebi, öğrencilerin toplumsallaşmasını sağlaması, onun toplumun bir üyesi olduğunu anlamasını, maddi manevi öğeleri öğrenmesini ve benimsemesine imkân oluşturmasıdır. Üçüncü olarak ise toplum kültürünü geliştirecek bireyler yetiştirmesidir (Büyükkaragöz ve Kesici, 1998'den akt; Baysal, Türkmen ve Yücel, 2010). Öğretmenlerin toplumumdaki rolleri günden güne artsa da statülerinin düşmesinin nedenleri arasında etkili ve katılımının yüksek olduğu bir meslek örgütüne sahip olamamaları gelmektedir. Zira meslekleşmenin göstergelerinden biri de meslek kuruluşlarıdır. Kendi üyelerinin çıkarlarını, haklarını korumak ve sorunlarını dile getirmek için organize olan meslek kuruluşları, öğretmenler için de söz konusudur (Tezcan, 1988)

Aydın'a (1999) göre öğretmen örgütleri, üyeleri arasında tanışma ve birliktelik sağlayarak öğretmenliğin meslekleşmesine katkıda bulunabilirler. Özellikle taşradaki meslekî kuruluşlar, öğretmenlerin buluşma ve meslekî sorunlarını tartışma yeri olabilir, her türlü meslekî sorunlarını araştırarak ilgililere duyurulmasını sağlayabilir ve bunların çözümüne katkıda bulunabilir. Yine hukuki ve ekonomik sorunları gibi birçok sorunu olan öğretmenler, uzman meslektaşlarının bulunduğu örgütte aydınlatıldığını düşünerek bu kuruluşlara başvurabilirler. Böylece bu örgütler, öğretmenler için önemli bir güvence teşkil etmekle birlikte kendilerini daha güçlü hissetmelerine olanak sağlamış olurlar.

Eğitim sendikaları üyelerinin çoğunluğunu oluşturan öğretmenler, topluma örnek olan ve eğitim sisteminin temelini oluşturan kişiler olup, toplumun kültürel yapısını şekillendiren en büyük etkenlerdendir. Bununla birlikte öğretmenler, meslekî olarak örgütlenme geleneğine sahip en eski kamu görevlileridir (Cerev, 2014). Sendikalar, demokrasinin yaşaması ve gelişmesi için mutlaka olması gereken örgütlü yapılardır (Tortop, 2005). Demokrasinin temeli özgürlük, çoğulculuk, eşitlik, katılımcılık ve uzlaşmaya dayanmaktadır. Sendikalar, demokrasinin bu temel ilkelerini hayata geçiren örgütlü yapılar oldukları için demokrasinin bugününün ve geleceğinin garantisi konumundadırlar (Özdemir, 2002). Yine sendikalar, eğitim alanında faaliyet gösteren sivil toplum kuruluşları arasında gerek üye sayısı gerekse etkililik açısından örgütlenmiş en büyük yapıyı (Erarslan, 2012b) oluşturmaktadırlar.

Sendika kavramı, Roma ve Yunan hukuk sistemlerinde rastlanan "syndic" terimi bir birliğin (sitenin) temsilini sağlamakla görevli kimseleri ifade ederken "Syndicat" terimi ise "syndic"in fonksiyonlarını ve bu fonksiyonların 
uygulanmasını ifade etmek için kullanılmıştır (Işık, 1962'den akt; Eraslan, 2012). Eğitim sendikaları, kamuda ve özel sektörde çalışarak eğitim-öğretim faaliyetlerine katılan öğretmenlerin çalışma ve hayat koşullarını iyileştirmek, geliştirmek ve dayanışmayı tesis etmek amacıyla kurulmuş sivil toplum örgütleridir. Eğitim sendikalarının genel amacı üyelerinin ortak ekonomik, sosyal, özlük, meslekî, sendikal hak ve çıkarlarını koruyup geliştirerek onlara daha saygın bir hayat düzeyi sağlamayı hedefleyen projeler geliştirmektir. $\mathrm{Bu}$ bağlamda eğitim alanındaki sendikalar kamu sendikacılığı yapmaktadır (Eraslan, 2012).

Türkiye'de öğretmen örgütlenmelerinin tarihsel gelişimi incelendiğinde bu faaliyetlerin uzun yıllara dayandığ 1 ve ilk olarak II. Meşrutiyet döneminde başladığı görülmektedir. İlk öğretmen örgütlenmesinin 1908 yılında gerçekleşmiş olduğu ancak sık sık kesintiye uğradığı anlaşılmaktadır. Öğretmen örgütlenmeleri, Akyüz'e (1978) göre 1908 Meşrutiyetinin getirdiği hürriyet havası, siyasi ve meslekî birçok cemiyetin (meslekî kuruluşun) kurulup çoğalmasına yol açmış ve bundan dolayı öğretmenler de bazı meslekî teşekküller kurmuşlardır. Türkiye'de ilk öğretmen meslek kuruluşu Darülfünun ve Darülmuallimin mezunlarının Temmuz 1908 inkılâbından hemen sonra İstanbul'da kurdukları, "Encümen-i Muallimin"dir. Encümen-i Mualliminin amacı öğretmenlerin haklarını savunmak ve eğitimin yayılması konusunda halkı uyarmaktır. Yine Akyüz (2016)'e göre bu öğretmen meslek kuruluşunun ilk isteği de eğitimin ülke geneline yayılmasının sağlanması, Avrupa'daki eğitim sistemi ve eğitimcilerden yararlanılması, ilköğretime önem verilmesi, öğretmenlerin maaşlarının iyileştirilmesi ve öğretmen tayininde kıdem ve ehliyete dikkat edilmesi olmuştur.

Cumhuriyet dönemi ile ülke genelinde kamu görevlilerinin örgütlenmesi çok önemli bir düzeyde olmasa da öğretmenler örgütlenme yoluna giderek başta Ankara olmak üzere yurdun çeşitli yerlerinde öğretmen örgütleri kurmuşlardır. Ankara merkezli kurularak zamanla ülke geneline yayılan, “Türkiye Muallime ve Muallimler Cemiyeti Birliği” bu süreçte güçlenerek özellikle siyasi etki ile 1925 yılında "Türkiye Muallimler Birliği”" ismini almıştır (Akyüz, 1978). Cumhuriyet sonrası, 1922-1946 yıllarını kapsayan dönem, örgütsüzlük ve durgunluk dönemi olmakla birlikte bu dönemin tarihe damgasını vurmuş en önemli olgusu Köy Enstitüleri olmuştur. 1946 yılında ise Türkiye Öğretmen Dernekleri Milli Federasyonu (TÖDMF) kurulmuştur. Türkiye genelinde öğretmen hareketinin ve örgütlenmesinin ikinci büyük 
kuruluşu olan "Türkiye Öğretmen Dernekleri Milli Federasyonu” 15 Ağustos 1948 günü görevini tamamlamış ve aynı gün "Öğretmen Yardımlaşma Dernekleri Birliği” kurulmuştur. Kuruluş tam olarak 1950 yılında tamamlanmış ve 1954 yılında ise "Türkiye Öğretmen Dernekleri Milli Federasyonu" ismini almıştır (Altunya, 2008). 1965 yılına gelindiğinde öğretmenlerin iki büyük sendika oluşturdukları gözlenmektedir. Bunlar, Türkiye Öğretmenler Sendikası (TÖS) ve Türkiye İlkokul Öğretmenleri Sendikası (ILLK-SEN) olmuştur (Güvenç, 2008). Fakat bu sendikalar 1971 askeri müdahalesi ile son bulmuş ve kamu görevlilerinin sendikalaşması yasaklanmıştır. Ancak öğretmenler hemen dernekleşmeye başlamışlardır. Bunlardan biri, öğretmenler tarafından kurulan Ülkücü Öğretim Üyeleri ve Öğretmenler Derneğidir (ÜLKÜ-BİR). ÜLKÜR-BİR, 1971 y1lında kurulmuş ve faaliyet gösterdiği dönem içinde 80.000 civarında üyeye ve 300'den fazla şubeye sahip olmuştur. Yine 1975 yılında Hürriyetçi Öğretmenler Yardımlaşma ve Dayanışma Birliği (HÜRÖĞRET-BİR) ve Mefkûreci Öğretmenler Derneği (MEF-DER) kurulmuş ve dolayısıyla bu dönem içinde faaliyet gösteren öğretmen dernekleri arasında girmişlerdir (Erarslan, 2012a). 1975 yılından sonra ülke genelinde meydana gelen ekonomik şartlar ile öğretmenlerin gittikçe kötüleşen ekonomik durumları sendikalaşma düzeyini artırmıştır. Dönem içinde kurulan diğer öğretmen dernekleri ise Hürriyetçi Öğretmenler Derneği (HÜR-DER), Teknik Öğretmenler Derneği (TÖD), Beden Eğitimi Öğretmenleri Derneği, Tüm İlköğretim Müfettişleri Derneği (TİM-DER), Tüm Öğretim Üyeleri Derneği (TÜMÖD), Anadolu ve Rumeli Öğretmen Dernekleri Federasyonu (Akyüz, 1978) olmuştur.

Öğretmen dernekleri, 12 Eylül 1980 askeri müdahale ile tekrar kapatılmıştır. Ancak 2001 yılında oluşturulan yasal zemin ile hızlı bir şekilde sendikalaşmaya başlamışlardır. Bu yasa çıkmadan önce kurulmuş olan sendikalara üye olan öğretmen sayısı hızlı bir şekilde artmıştır. Bu durum diğer kamu görevlilerine örnek olmuş ve onların da sendikalaşmasının önünü açmıştır. $\mathrm{Bu}$ nunla birlikte dönem içerisinde eğitim sendikalarının çabaları sonucu üst kuruluş olan konfederasyonlar kurulmuştur.

Öğretmen örgütlerinin son yıllardaki durumu ile ilgili olarak anayasanın sivilleştirilme çalışmaları 1şığında gerçekleşen 07.05.2010 tarih ve 5982 sayılı Türkiye Cumhuriyeti Anayasasının Bazı Maddelerinde Değişiklik Yapılması Hakkında Kanun 12 Eylül 2010 tarihinde halk oylaması ile kabul edilmiştir. Anayasada yapılan sendika hakkına ilişkin değişikliklerden ilki, 
anayasanın "Sendika Kurma Hakkı" başlıklı 51. maddesinin son fikrasının yürürlükten kaldırılması olmuş ve böylece bir kişinin aynı zamanda ve aynı iş kolunda birden fazla sendikaya üye olmasının yolu açılmıştır. Bu değişikliklerle birlikte memurlar ve diğer kamu görevlilerine toplu sözleşme hakkı tanınmıştır (Yıldız, 2015).

Türkiye'de eğitim çalışanları da dâhil kamu görevlilerinin üye oldukları sendikalarının hak ve sorumluluklarını belirleyen 4688 numaralı kanunda sendikaların hangi faaliyetlerde bulunabilecekleri belirtilmiştir. Bunlardan bazıları şöyle sıralanabilir:

a. Genel olarak kamu personelinin hak ve ödevleri, çalışma koşulları, yükümlülükleri, iş güvenlikleri ile sağlık koşullarının geliştirilmesi konularında görüş bildirmek ve toplu görüşme sonucunda anlaşmaya varlan mutabakat metinlerinin uygulanmasinı izlemek üzere idarî kurullara üyeleri arasindan temsilciler göndermek.

b. Devlet personel mevzuatında kamu görevlilerinin temsilini öngören çeşitli kurullara temsilci göndermek.

c. Verimlilik araştırmalar yapmak, sonuçlarla ilgili raporlar düzenlemek, önerilerde bulunmak ve işverenlerle bu konularda ortak çalışmalar yapmak.

d. Üyelerin meslekî yeterliliklerinin artırllması ve sorunlarının çözülmesi ile sendikal faaliyetlerinin geliştirilmesine yönelik kurs, seminer ve sosyal amaçlı toplantılar düzenlemek, bilimsel çalışmalar yapmak ve yayinlarda bulunmak.

e. Üyelerin ortak ekonomik ve sosyal hak ve menfaatleri ile personel hukukunu ilgilendiren konularda ilgili kurumlara ve yetkili makamlara sunulmak üzere çalışmalar yapmak ve öneriler getirmek.

f. Üyelerin idare ile ilgili doğacak ihtilaflarında, ortak hak ve menfaatlerinin izlenmesinde veya hukukî yardım gerekliliğinin ortaya çıması durumunda üyelerini veya mirasçılarını, her düzeyde ve derecedeki yönetim ve yargl organları önünde temsil etmek veya ettirmek (...) (Resmî Gazete, 2012).

Buna göre kamu görevlileri, çalıştıkları kurum veya kuruluşların hizmet kolunda kurulmuş olan sendikalara üye olabileceklerdir. Çalışma ve Sosyal Güvenlik Bakanlığ1 (ÇSGB), öğretmen örgütlerini 02 sıra no'lu hizmet kolu olan "Eğitim, Öğretim ve Bilim Hizmetleri" hizmet iş kolu içerisinde tanımlamıştır (ÇSGB, 2012). Tablo 1'de "Eğitim, Öğretim ve Bilim Hizmetleri" hizmet kolunda açılmış olan sendikalara üye olabilecek kişilerin çalıştığı kurum ve kuruluşlar görülmektedir. Bu kurum ve kuruluşlarda çeşitli unvanlar altında çalışanlar eğitim, öğretim ve bilim hizmet kolunda kurulmuş herhangi bir sendikaya üye olabilmektedir. 
Tablo 1. Eğitim, Öğretim ve Bilim Hizmet Koluna Giren Kamu Kurum ve Kuruluşları

\begin{tabular}{ll}
\hline Kurum Kodu & Kurum ve Kuruluşlar \\
\hline 01 & Milli Eğitim Bakanlığı \\
02 & Türkiye Orta Doğu Amme İdaresi Enstitüsü Genel Müdürlüğ̈̈ \\
04 & Yüksek Öğretim Kurulu Başkanlığı \\
05 & Üniversiteler Arası Kurul Başkanlığı \\
06 & Öğrenci Seçme ve Yerleştirme Merkezi Başkanlığı \\
07 & Üniversiteler \\
08 & İleri teknoloji Enstitüleri \\
\hline 09 & Yüksek Öğrenim, Kredi ve Yurtlar Kurumu Genel Müdürlüğü \\
\hline
\end{tabular}

Memur sendikalarının 2017 yılına ait resmi üye sayıları, 5 Temmuz 2017 tarihli Resmî Gazete'de yayımlanan 4688 Sayılı "Kamu Görevlileri Sendikaları ve Toplu Sözleşme Kanunu Gereğince Kamu Görevlileri Sendikaları ile Konfederasyonların Üye Sayılarına İlişkin, 2017 Temmuz İstatistikleri Hakkında Tebliğ" ile açıklanmıştır (Resmî Gazete, 05.07.2017). En çok üyesi olan 5 konfederasyona ait bilgiler Tablo 2'de görülmektedir.

Tablo 2. Bazı Sendikalar ve Üye Say1ları

\begin{tabular}{lllll}
\hline Sendika No & Sendika Adı & Konfederasyon & Üye Sayısı (N) & Oran (\%) \\
\hline 12 & TÜRK EĞİTIM-SEN & TÜRKIYYE KAMU-SEN & 201.282 & 17.37 \\
14 & EĞİTIM-SEN & KESK & 93.143 & 8.03 \\
28 & EĞİTIM-BİR-SEN & MEMUR-SEN & 420.149 & 36.26 \\
120 & EĞİTIM-İŞ & BİRLEŞİK KAMU-İŞ & 48.993 & 4.22 \\
125 & TEÇ-SEN & BAĞIMSIZ & 7.564 & 0.65 \\
\hline & Toplam & 771.131 & \\
\hline
\end{tabular}

Tablo 2'de görüldüğü gibi eğitim, öğretim ve bilim hizmet kolunda ÇSGB'nin 2017 yılı verilerine göre 38 farklı sendika bulunmaktadır. Bu iş kolunda toplam 1.158.578 kişi bulunmaktadır. ÇSGB, 2017 istatistiklerine göre eğitim iş kolunda öğretmen ve diğer eğitim çalışanlarının yaklaşık 780.000'inin sendika üyesi olduğunu belirtmektedir. Bu verilere göre eğitim alanında sendikalaşma oranı yaklaşık \%67.5'tir.

Eğitim, öğretim ve bilim hizmet kolunda çok sayıda sendikanın bulunmasının birçok sebebinin olduğu görülmektedir. Eraslan'ın (2012a) belirttiği gibi, Türkiye'de siyasi iktidarlar, güç yetkisi vermediği sendikaları kendi politik çıkarları uğruna çok rahat manipüle edebilmektedir. Hangi ideolojiden olursa olsun her siyasi iktidar kendi görüşüne yakın olan sendikalarla iş birliğine gitmekte, onlardan destek almakta, onlara destek vermekte ve gelişmelerine katkı sağlamaktadır. Bu gelişme, nitel bağlamda değil nicel bağlamda olmaktadır. Üye sayısı fazla olan sendikanın yetkili sayıldığı yasal düzenleme 
kapsamında toplu sözleşme masasında kendi kontrolündeki bir sendikanın olması siyasi iktidarın işini kolaylaştırabilmektedir. Dönemler ve aktörler değişse bile her bir dönem belirli ideolojik zemininde yeni örgütlenmelerini yaratmıştır.

Öğretmenlerin meslekî örgütlenmeleri ile ilgili bazı araştırmaların yapıldığ1 görülmektedir (Baysal, Türkmen ve Yücel, 2010; Can, 2002; Demir, 2014; Eraslan, 2012, 2012a; Kara, 2016; Karataş, 2015; Taşdan, 2013; Tok, 1996; Yalçın, 2018). Bu araştırmalardan bazılarının tarihsel tarama şeklinde, bazılarınsa nitel araştırma şeklinde olduğu görülmektedir. Yine bu araştırmaya benzer çalışmaların yapılmış olduğu görülmekle birlikte Burdur ili özelinde ve hem nicel hem de kısmen nitel özellikler taşıdığ 1 için bu araştırmanın diğerlerinden farklı bir yere sahip olduğunu söylemek mümkündür. Nicel veriler Öğretmenlerinin Meslekî Örgütlenmeye Yönelik Tutumları Ölçeği şeklinde toplanmış; diğer veriler ise yarı yapılandırılmış bir şekilde ve "Son beş yılda sendika değiştirdiniz mi? Değiştirdiniz ise neden?" sorusu ile bir araya getirilmiştir.

Öğretmenlerin her alanda olduğu gibi özellikle meslek bilincinin oluşturulmasında ve sendikal hakların kazanılmasında öncü oldukları görülmektedir. Türkiye'de eğitim sendikalarının oluşum ve gelişim süreci, öğretmenlerin sendikalaşmaya olan eğilimleri, meslekî örgütlenmeye ilişkin tutumları, sendikalara üye olma nedenleri, sendikaları seçmelerine etki eden faktörler ile sendikalardan beklentilerinin belirlenmesi öğretmenlerin örgütlenme sorunlarının çözümüne 1şık tutacağı düşünüldüğü için bu durum araştırmanın çıkış noktasını oluşturmuştur.

\section{Araştırmanın Amacı ve Önemi}

Toplumda öğretmenlerin görev ve sorumluluklarının yanında sorunları da bulunmaktadır. Bu sorunlardan biri de öğretmenlerin sendikalaşması meselesidir. Dolayısıyla araştırmanın amacını öğretmenlerin meslekî örgütlenme ile ilgili görüşlerinin incelenmesi ile öğretmenlerin sendika değişikliği yapıp yapmadıklarının belirlenip değerlendirilmesi oluşturmuştur. Diğer bir ifade ile öğretmenlerin hukuki, sosyal ihtiyaçlarını karşılamak ve özlük haklarını korumak için kurdukları meslekî örgütlere karşı tutumlarının incelenmesi araştırmanın amacını oluşturmuştur.

Öğretmenlerin görev ve sorumluluklarını yerine getirirken haklarını elde edebilmeye ve koruyabilmeye dair ihtiyaçları sendikalaşma sorununu 
ortaya çıkarmıştır. Öğretmenlerin kendi içlerinde meslekî kurum ve kuruluşlara mensup olmalarının onlara gerek statü ve güç kazandırdığını söylemek mümkündür. Öğretmen sorunlarının çözümünde başka insanlara ve meslekî kuruluşlara ihtiyaç vardır. Öğretmenlerin meslekî ve toplumsal rollerini yerine getirebilmeleri için sendikalaşması bir zorunluluk hâline gelmiştir. Öğretmenlerin sendikalaşması, sendikalara üye olması ya da olmaması, sendika değiştirip değiştirmemesi ve sendikacılık anlayışlarının incelenmesi bu araştırmayı önemli kılan unsurlar arasındadır. Toplanan verilerin hem nicel olması hem de açık uçlu yarı yapılandırılmış soru elde dilmesi ve birlikte değerlendirilmesi bu araştırmaya bir yenilik getirmiştir. Ayrıca bu araştırmanın yeni yapılacak araştırmalara da kaynaklık edeceği düşünülmektedir.

\section{Araştırmanın Problemi}

$\mathrm{Bu}$ araştırmanın problemini "Öğretmenlerinin meslekî örgütlenmeye yönelik tutumları nasıldır?” sorusu oluşturmaktadır. Araştırmanın Alt Problemleri ise şöyledir:

1. Öğretmenlerin meslekî örgütlenmeye karşı görüşleri nasıldır?

2. Öğretmenler neden örgütlenmektedir?

3. Öğretmenlerin meslekî örgütlenmeye karşı olumlu olumsuz görüşleri nelerdir?

4. Öğretmenlerin meslekî örgütlerden beklentileri nelerdir?

5. Öğretmenlerin meslekî örgütlenme ile ilgili görüşleri cinsiyet, kıdem, branş ve eğitim durumlarına göre farklılaşmakta mıdır?

6. Öğretmenlerin sendika değiştirme-değiştirmeme nedenleri nelerdir?

\section{Araştırmanının Sınırlılıkları}

Araştırma 2016-2017 Eğitim-Öğretim yılında, Burdur ili merkezinde ve ilçelerde bulunan Milli Eğitim Bakanlığına bağlı okullarda görev yapan öğretmenlerin görüşleri ile sınırlıdır. Araştırmada elde edilen bulgular "Öğretmenlerinin Meslekî Örgütlenmeye Yönelik Tutumları” başlığıyla uygulanan ölçekteki sorular ile sınırlandırılmıştır. Öğretmenlerin sendika değişikliği yapıp yapmadıkları ise "Son beş yılda sendika değişikliği yaptınız mı?” şeklindeki açık uçlu soruya verdikleri cevaplarla sınırlandırılmıştır.

\section{Yöntem}

\section{Araştırmanın Modeli}

Araştırmada belirlenen temel amaca ulaşabilmek için nicel araştırma yöntemlerinden tarama modeli kullanılmıştır. Araştırmada genel tarama 
modellerinden olan ilişkisel tarama modeli kullanılmıştır. Araştırmanın nicel boyutunun verileri Baysal, Türkmen ve Yücel'in (2010) geliştirdiği “Sınıf Öğretmenleri ve Yöneticilerinin Meslekî Örgütlenme Tutumları Ölçeği” ile öğretmenlerin sendika değişikliği yapma veya yapmama nedenlerine ilişkin veriler ise yarı yapılandırılmış görüşme yöntemi ile elde edilmiştir.

Tarama modelleri, geçmişte ya da hâlen var olan bir durumu olduğu şekliyle betimlemeyi amaçlayan araştırma yaklaşımlarıdır (Karasar, 2009). Balcı'ya (2010) göre betimsel araştırmalar geçmişe dönük yapıldıklarında "ne idi?"yi ortaya koyarlar. Eğitim ile ilgili araştırmalar, "betimsel araştırma" olup eğitimin ilk ve temel araştırma eylemidir. Eğitim sorunlarının pek çoğu da betimsel nitelik taşımaktadır.

\section{Veri Toplama Araçları ve Verilerin Analizi}

Veri toplama aracı olarak Baysal, Türkmen ve Yücel (2010)'in geliştirdiği 35 maddeden oluşan "Sınıf öğretmenleri ve Yöneticilerinin Meslekî Örgütlenme Tutumları Ölçeği” uygulanmıştır. Ayrıca araştırmada buna ek olarak öğretmenlerin sendika değişikliği yapma veya yapmama nedenlerine ilişkin verileri elde etmek için yarı yapılandırılmış açık uçlu sorular sorulmuş ve bununla ilgili veriler toplanmıştır. Elde edilen nicel veriler bilgisayar paket programlan kullanılarak betimsel istatistik, bağımsız örneklemler $t$ Testi ve tek yönlü varyans analizi (ANOVA) ile test edilmiştir. Yarı yapılandırılmış açık uçlu soruyla elde edilen veriler ise betimsel analiz ve içerik analizi ile değerlendirilmiştir.

Betimsel analiz ve içerik analiziyle değerlendirme sürecinde elde edilen nitel veriler kelime ve cümle birimlerine ayrılarak incelenmiştir (Yıldırım ve Şimşek, 2011). Verilerin kodlanmasında ise genel bir çerçeve içinde yapılan kodlama (Strauss ve Corbin, 1997'den akt; Yıldırım ve Şimşek, 2011) kullanılmıştır. Yapılan bu analiz sonucunda bulgular öğretmen görüşleriyle desteklenmiştir.

Sınıf Öğretmenlerinin Meslekî Örgütlenmeye Yönelik Tutumları Ö1çeği'nde likert tipi soruların geçerliği için önce uzman görüşüne başvurulmuş daha sonra da bu sorular faktör analizine tabi tutularak soruların ölçebileceği boyutlar ortaya çıkarılmıştır. Güvenirlik ve faktör analizi sonucu başlangıçta 50 madde olan ölçme aracındaki madde sayısı 35'e düşürülmüştür. Ölçeğin en son hâliyle Cronbach $(\infty)$ güvenirlik katsayısının 0.91 olduğu görülmüştür. Verilerin analizi sırasında öğretmenlerin her bir soru veya ifadeye yönelik 
görüşleri tamamen katılıyorum (5), katılıyorum (4), kararsızım (3) katılmıyorum (2) ve kesinlikle katılmıyorum (1) seçenekleri arasında değişmiş ve puanlanmıştır (Baysal, Türkmen ve Yücel, 2010).

$\mathrm{Bu}$ araştırmada, verilerin değerlendirilmesinde; $p$ değeri 0.01 ile 0.05 aralığında; istatistiksel olarak anlamlı fark, $p$ değeri 0.001 ile 0.01 aralı̆̆ında; yüksek düzeyde olarak anlamlı fark, $p$ değeri 0.001 'den daha küçük ise; çok yüksek düzeyde istatistiksel olarak anlamlı fark ve $p$ değeri 0.10 ile 0.05 aralığında; sinırda anlamlılık -marginally significant- anlamına gelmektedir (Kul, 2014).

\section{Evren ve Örneklem}

Araştırmanın evrenini 2016 yılında Burdur il merkezi, ilçe ve köylerinde görev yapan 3346 öğretmen oluşturmaktadır. Çalışmanın örneklemi ise 0.05 güven aralığında ve 0,5 görülme sıklığı ele alınarak örneklem formülü aracılığıyla (Tanrıöğen, 2009) hesaplanmış ve 344 kişi olarak bulunmuştur. Ancak araştırmanın örneklemini bu evrenden tabakalama örnekleme yöntemi ile seçilen 778 öğretmen oluşturmaktadır.

Verilerin toplanmasında ise iki aşamalı basit tesadüfi örnekleme yöntemi kullanılmıştır. Buna göre ilk aşamada Burdur il genelinde basit tesadüfi örnekleme yöntemiyle Merkez, Bucak, Tefenni, Ağlasun, Karamanlı ve Çeltikçi ilçeleri belirlenmiş; ikinci aşamada ise bu merkezlerdeki kurumlar arasından örneklemin üç katı sayıya kadar katılımcı oluşturacak kurumlar "basit tesadüfî örnekleme" yöntemiyle seçilmiştir. Gerekli izinler alınarak bu okullarda görev yapan öğretmenlere formlar dağıtılmıştır. Veri toplama araçlarından 825 'si geri dönmüştür. Eksik bilgi ve değişkenlerin işaretlenmemesi gibi nedenlerden dolayı 47 form değerlendirme dışı bırakılmıştır. Son durumda Burdur ili merkezinden 469, Bucak ilçesinden 154, Tefenni'den 42, Ağlasun'dan 41, Karamanlı'dan 51, Çeltikçi'den 21 olmak üzere araştırmanın örneklemini oluşturan 778 öğretmen görüşü değerlendirmeye alınmıştır. Araştırmanın örneklemi ile ilgili bilgiler Tablo 3'te verilmiştir.

Tablo 3'te görülebileceği gibi araştırmaya $426(\% 54,8)$ erkek ve 352 $(\% 45,2)$ kadın olmak üzere toplam 778 öğretmen katılmıştır. Araştırmaya katılan öğretmenlerin 41'i $(\% 5,29)$ öğretmen okulu ve eğitim enstitüsü mezunu, 72'si (\%9,3) eğitim yüksekokulu, 528'i (\%67.9) Eğitim Fakültesi, 79'u $(\% 10,2)$ Fen Edebiyat Fakültesi, 58'i $(\% 7,5)$ ise diğer fakültelerden (Ticaret Turizm, Ziraat, İktisadi ve İdari Bilimler fakülteleri gibi) mezun olmuştur. 
Öğretmenlerin 118'i (\%10,8) 21-30 yaş grubu aralığında, 321'i (\%21,7) 3140 yaş grubu aralığında, 245'i (\%19,7) 41-50 yaş grubu aralığında, 94'ü $(\% 13,4) 51$ ve üstü yaş grubu aralığında bulunmaktadır. Öğretmenlerin meslekî kıdemleri incelendiğinde; 84'ü $(10,8)$ 1-5 yıl kıdeme, 169'u (\%21,7) 6-10 y1l k1deme, 153'ü (\%19,7) 11-15 y1l k1deme, 104'ü (\%13,4) 16-20 y1l k1deme, 114 'ü $(\% 14,7)$ 21-25 yıl kıdeme ve 154'ü $(\% 19,8) 26$ y1l ve üstü k1deme sahiptir.

Tablo 3. Araştırmanın Örneklemine Ait Dağılımı

\begin{tabular}{|c|c|c|c|}
\hline \multicolumn{2}{|l|}{ Değişkenler } & N (Dağılım) & \% (Dağılım) \\
\hline \multirow[t]{3}{*}{ Cinsiyet Dağılımı } & Kadın & 352 & 45.2 \\
\hline & Erkek & 426 & 54.8 \\
\hline & Toplam & 778 & 100.0 \\
\hline Mezun Olunan & Öğretmen Okulu ve Eğt. Enst. & 41 & 5.29 \\
\hline \multirow[t]{4}{*}{ Okul Türü } & Eğitim Y. O. & 72 & 9.3 \\
\hline & Eğitim Fakültesi & 528 & 67.9 \\
\hline & Fen Edebiyat Fakültesi & 9 & 10.2 \\
\hline & Diğer Fakülteler & 58 & 7.5 \\
\hline \multirow[t]{4}{*}{ Yaş Grubu } & 21-30 yaş & 118 & 10.8 \\
\hline & $31-40$ yaş & 321 & 21.7 \\
\hline & $41-50$ yaş & 245 & 19.7 \\
\hline & 51 yaş ve üstü & 94 & 13.4 \\
\hline \multirow[t]{17}{*}{ Branş Durumu } & Sınıf Öğretmeni & 228 & 29.3 \\
\hline & Türkçe Öğretmeni & 48 & 6.2 \\
\hline & Sosyal Bilgiler Öğretmeni & 39 & 3.7 \\
\hline & Matematik Öğretmeni & 37 & 4.8 \\
\hline & Yabancı Dil Öğretmeni & 73 & 9.4 \\
\hline & Din. Kül. ve Ahlak Bil. & 23 & 3.0 \\
\hline & Beden Eğitimi & 31 & 4.0 \\
\hline & Güzel Sanatlar Grubu & 30 & 3.9 \\
\hline & Fen ve Teknoloji & 38 & 3.6 \\
\hline & Orta Öğr. Fen & 33 & 3.3 \\
\hline & Tarih & 23 & 3.0 \\
\hline & Coğrafya & 14 & 1.8 \\
\hline & Edebiyat & 47 & 6.0 \\
\hline & Felsefe grubu & 35 & 4.5 \\
\hline & Meslek Öğretmeni & 41 & 5.2 \\
\hline & Ort. Öğrt. Matematik & 21 & 2.7 \\
\hline & Okul Öncesi & 37 & 4.8 \\
\hline \multirow{4}{*}{$\begin{array}{l}\text { Çalıșılan Okul } \\
\text { Türü }\end{array}$} & Temel Eğitim & 280 & 36 \\
\hline & Ortaokul & 227 & 29.2 \\
\hline & Genel Lise & 134 & 17.2 \\
\hline & Meslek Lisesi & 137 & 17.6 \\
\hline \multirow{3}{*}{$\begin{array}{l}\text { Görev Yapılan } \\
\text { Yer }\end{array}$} & İl merkezi & 469 & 60.3 \\
\hline & İlçe merkezi & 248 & 31.9 \\
\hline & Köy ve belde & 61 & 7.9 \\
\hline
\end{tabular}

Öğretmenlerin branş durumuna göre dağılımları incelendiğinde 228 'i $(\% 29,3)$ sinıf öğretmeni, 48’i $(\% 6,2)$ Türkçe öğretmeni, 39’u $(\% 3,7)$ sosyal 
bilgiler öğretmeni, 37'si $(\% 4,8)$ matematik öğretmeni, 73’ü $(\% 9,4)$ yabanc1 dil öğretmeni, 23’ü (\%3,0) din kültürü ve ahlak bilgisi öğretmeni, 31'i (\%4,0) beden eğitimi öğretmeni, 30’u $(\% 3,9)$ güzel sanatlar grubu (resim-görsel sanatlar-teknoloji tasarım-müzik) öğretmeni, 38 'i $(\% 3,6)$ fen ve teknoloji öğretmeni, 33'ü $(\% 3,3)$ ortaöğretim fen bilimleri (fizik-kimya-biyoloji) öğretmeni, 23 'ü $(\% 3,0)$ tarih öğretmeni, 14'ü $(\% 1,8)$ coğrafya öğretmeni, 47'si $(\% 6,0)$ edebiyat öğretmeni, 35 'i $(\% 4,5)$ felsefe grubu (psikoloji, felsefe, rehberlik) öğretmeni, 41'i $(5,2)$ meslek öğretmeni, 21 'i $(\% 2,7)$ ortaöğretim matematik öğretmeni ve 37'si $(\% 4,8)$ okul öncesi öğretmenidir.

Öğretmenlerin çalıştığı okul türüne ilişkin dağılımları incelendiğinde; 280'i (\%36) temel eğitimde, 227'si (\%29,2) ortaokulda, 134'ü $(\% 17,2)$ genel lisede, 137'si $(\% 17,6)$ ise meslek liselerinde görev yapmaktadır. Yine öğretmenlerin 469'u $(\% 60,3)$ il merkezinde, 248'i $(\% 31,9)$ ilçe merkezinde, 61'i $(\% 7,8)$ ise belde-köylerde görev yapmaktadır. Öğretmenlerin 636's1 $(\% 81,7)$ sendika üyesiyken, 142'si $(\% 18,3)$ ise sendika üyesi değildir. Kadın öğretmenlerin 253'ü $(\% 71,9)$ sendika üyesi, 99'u $(\% 28,1)$ sendika üyesi değildir. Erkek öğretmenlerin ise 383'ü (\%89.9) sendika üyesi iken, 43'ü $(\% 10,1)$ sendika üyesi değildir. Öğretmenlerin 142'si $(\% 18,3)$ sendika üyesi değilken, 226's1 (\%29,0) 1-5 y1ldır sendika üyesi, 141'i (\%18,1) 6-10 yıldır sendika üyesi, 94'ü (\%1211) 11-14 yıldır sendika üyesi, 175'i $(\% 22,5)$ ise 15 yıl ve üstü y1l sendika üyesidir. Öğretmenlerin 280'i $(\% 36,0)$ sendika değişikliği yapmışken, 498'i $(\% 64,0)$ sendika değişikliği yapmamıştır.

\section{Bulgular ve Yorum}

$\mathrm{Bu}$ bölümde araştırmanın amacını teşkil eden, öğretmenlerin meslekî örgütlenme (sendikalaşma) ile ilgili görüşlerinin incelenmesi ve öğretmenlerin sendika değişikliği yapıp yapmadıklarının belirlenebilmesi için cevap aranan ana problem ve alt problemler için toplanan verilerin analiz edilmesi ile elde edilen bulgular ve yorumlarına yer verilmiştir.

\section{Araştırmanın Birinci Alt Problemi}

"Öğretmenlerin meslekî örgütlenmeye karşı görüşleri nasıldır?" sorusuna ilişkin veriler Tablo 4'te yer almaktadır.

Tablo 4'te öğretmenlerin meslekî örgütlenmeleriyle ilgili görüşlerinin cinsiyete göre dağılımları yapılan bağımsız $\mathrm{t}$ Testi sonuçları incelendiğinde genel boyutta anlamlı bir farklılık göstermemektedir [t(776)=1.35, $\mathrm{p}>.05]$. 
Tablo 4. Öğretmenlerin, Meslekî Örgütlenmeye Karşı Görüşlerinin Değişimi ve Dağılımı

\begin{tabular}{llllllll}
\hline Boyutlar & Cinsiyet & $\mathbf{N}$ & $\overline{\mathbf{x}}$ & $\mathbf{S}$ & $\mathbf{s d}$ & $\mathbf{t}$ & $\boldsymbol{p}$ \\
\hline \multirow{2}{*}{ Genel } & Kadın & 352 & 138.88 & 15.91 & 776 & 1.35 & .175 \\
Boyut & Erkek & 426 & 137.30 & 16.29 & & & \\
& Toplam & 778 & 138.01 & & & & \\
\hline \multirow{2}{*}{ Sendikalara Üye } & Kadın & 352 & 22.10 & 3.29 & 776 & 3.22 & .001 \\
Olma Nedenleri & Erkek & 426 & 22.89 & 3.51 & & & \\
& Toplam & 778 & 22.54 & & & & \\
\hline \multirow{2}{*}{ Sendikalara Üye } & Kadın & 352 & 56.04 & 10.40 & 776 & 3.11 & .002 \\
Olmama Nedenleri & Erkek & 426 & 53.50 & 12.06 & & & \\
& Toplam & 778 & 54.65 & & & & \\
\multirow{2}{*}{ Sendika Seçimi } & Kadın & 352 & 17.01 & 3.22 & 776 & .476 & .634 \\
Etkileyen Faktörler & Erkek & 426 & 16.89 & 3.69 & & & \\
& Toplam & 778 & 16.95 & & & & .497 \\
\multirow{2}{*}{ Sendikalardan } & Kadın & 352 & 43.70 & 6.14 & 776 & .679 & \\
Beklentileri & Erkek & 426 & 44.00 & 5.95 & & & \\
\hline & Toplam & 778 & 43.87 & & & & \\
\hline
\end{tabular}

Alt boyutlar incelendiğinde öğretmenlerin meslekî örgütlere üye olma nedenleri boyutunda erkeklerin lehine anlamlı farklılık ortaya çıkmıştır $[\mathrm{t}(776)=3.22, p<.05]$. Bu sonuçtan erkek öğretmenlerin $(\overline{\mathrm{x}}=22.89)$, kadın öğretmenlere göre $(\overline{\mathrm{x}}=22.10)$ sendika üyesi olma nedenlerinde daha olumlu bir tutuma sahip oldukları söylenebilir. Öğretmenlerin sendika üyesi olmama nedenleri boyutu incelendiğinde kadın öğretmenlerin lehine anlamlı farklılık ortaya çıkmıştır $[\mathrm{t}(776)=3.11, p<.05] . \quad \mathrm{Bu}$ sonuçtan kadın öğretmenler $(\overline{\mathrm{x}}=56.04)$, sendika üyesi olmama konusunda erkek öğretmenlerden $(\overline{\mathrm{x}}=53.50)$ daha olumlu tutuma sahip oldukları söylenebilir. Ancak sendika seçimini etkileyen faktörler boyutunda $[\mathrm{t}(776)=.476, p>.05]$ ve sendikalardan beklentileri boyutunda anlamlı bir farkl1lık görülmemektedir $[\mathrm{t}(776)=.679, p>.05]$.

Tablo 5'te görüleceği gibi, yapılan tek yönlü varyans analizi sonucunda öğretmenlerin meslekî örgütlenme ile ilgili genel görüşleri arasında anlamlı bir fark olmadığ 1 ortaya çıkmıştır [F(4.773)=1.764, $p>$ >.05]. Başka bir deyişle öğretmenlerin meslekî örgütlenmeye ilişkin görüşleri mezun oldukları okula göre anlamlı bir şekilde değişmemektedir. Yine öğretmenlerin sendikaya üye olma nedenleri $[\mathrm{F}(4.773)=.683, p>.05]$, sendikaya üye olmama nedenleri $[\mathrm{F}(4.773)=1.274, p>.05]$, sendika seçimini etkileyen faktörler $[\mathrm{F}(4.773)=.375$, $p>.05]$ ve sendikalardan beklentileri boyutunda anlamlı bir farkl1lık görülmemektedir $[\mathrm{F}(4.773)=2.012, p>.05]$ 
Tablo 5. Öğretmenlerin Meslekî Örgütlenmeye Dair Görüşlerinin Mezun Olunan Okul Türüne Göre Dağılımı

\begin{tabular}{llllllll}
\hline Boyutlar & $\begin{array}{l}\text { Varyansın } \\
\text { Kaynağı }\end{array}$ & $\begin{array}{l}\text { Kareler } \\
\text { Toplamı }\end{array}$ & Sd & $\begin{array}{l}\text { Kareler } \\
\text { Ortalaması }\end{array}$ & F & P & Fark \\
\hline Genel Boyut & Gruplar aras1 & 1829.03 & 4 & 457.258 & 1.764 & .134 & - \\
& Gruplar içi & 200345.53 & 773 & 259.179 & & & \\
& Toplam & 202174.56 & 777 & & & & \\
\hline Sendikalara Üye & Gruplar arası & 32.32 & 4 & 8.082 & .683 & .604 & - \\
Olma Nedenleri & Gruplar içi & 9147.25 & 773 & 11.833 & & & \\
& Toplam & 9179.58 & 777 & & & & \\
\hline Sendikalara & Gruplar aras1 & 661.94 & 4 & 165.485 & 1.274 & .279 & - \\
Üye Olmama & Gruplar içi & 100399.27 & 773 & 129.883 & & & \\
Nedenleri & Toplam & 101061.22 & 777 & & & & \\
\hline Sendika Seçimini & Gruplar arasi & 18.30 & 4 & 4.577 & .375 & .827 & - \\
Etkileyen & Gruplar içi & 9434.65 & 773 & 12.205 & & & \\
Faktörler & Toplam & 9452.96 & 777 & & & & \\
\hline Sendikalardan & Gruplar aras1 & 291.75 & 4 & 72.939 & 2.012 & .091 & - \\
Beklentileri & Gruplar içi & 28016.71 & 773 & 36.244 & & & \\
\hline
\end{tabular}

Tablo 6'da ise yapılan tek yönlü varyans analizi sonucunda öğretmenlerin kıdemlerine göre meslekî örgütlenme ile ilgili genel görüşleri arasında anlamlı bir fark olduğu görülmektedir $[\mathrm{F}(5.772)=3.333, p<.05]$. Bu görüş farklılığının hangi gruplar arasında olduğunu belirlemek amaciyla yapılan Scheffe Testi sonuçlarına göre 6-10 yıl kıdeme sahip öğretmenler $(\bar{x}=140.14$, $S=14.00), 26$ yıl ve üstü kıdeme sahip öğretmenlerden $(\bar{x}=134.06, S=18.41)$ daha olumlu tutuma sahiptirler. Scheffe'nin yöntemi de aile olarak hata oranını denetlemektedir. Bu yöntem yalnızca çift olarak karşılaştırmalar için düzeltme yapmaz, aynı zamanda belirleyeceğiniz her türlü olası karşılaştırmalar için de düzeltme yapmaktadır (www.ibim.com. 2020).

Öğretmenlerin kıdemleri göz önünde bulundurulduğunda sendikalara üye olma nedenleri boyutunda anlamlı bir farkl1lık görülmemektedir $[\mathrm{F}(5.772)=.840, p>.05]$. Ancak öğretmenlerin sendikalara üye olmama nedenleri boyutunda da anlamlı bir farkl1lık görülmektedir [F(5.772) $=4.964, p<.05]$. $\mathrm{Bu}$ görüş farklılığının hangi gruplar arasında olduğunu belirlemek amaciyla yapılan Scheffe Testi sonuçlarına göre 6-10 yıl kıdeme sahip öğretmenler $(\overline{\mathrm{x}}=56.77, \mathrm{~S}=11.53), 26$ yıl ve üstü kıdeme sahip öğretmenlerden $(\overline{\mathrm{x}}=51.20$, $\mathrm{S}=12.78$ ) daha olumlu görüşe sahiptir. Ayrıca 21-25 yıl kıdeme sahip öğretmenler ( $\bar{x}=55.98, S=10.03), 26$ ve üstü kıdeme sahip öğretmenlerden $(\overline{\mathrm{x}}=51.20, \mathrm{~S}=12.78)$ daha olumlu görüşe sahip oldukları görülmektedir. Öğretmenlerin sendika seçimini etkileyen faktörler $[\mathrm{F}(5.772)=1.229, p>.05]$ ve 
sendikalardan beklentileri boyutunda anlamlı bir farklılık görülmemektedir $[\mathrm{F}(5.772)=.920, p>.05]$.

Tablo 6. Öğretmenlerin Meslekî Örgütlenme ile İlgili Görüşlerinin Kıdemlerine Göre Değişimi

\begin{tabular}{|c|c|c|c|c|c|c|c|}
\hline Boyutlar & $\begin{array}{l}\text { Varyansın } \\
\text { Kaynağı }\end{array}$ & $\begin{array}{l}\text { Kareler } \\
\text { Toplamı }\end{array}$ & Sd & $\begin{array}{l}\text { Kareler } \\
\text { Ortalaması }\end{array}$ & $\mathbf{F}$ & $p$ & Fark \\
\hline Genel Boyut & $\begin{array}{l}\text { Gruplar arası } \\
\text { Gruplar içi } \\
\text { Toplam }\end{array}$ & $\begin{array}{l}4271.82 \\
197902.73 \\
202174.56\end{array}$ & $\begin{array}{l}5 \\
772 \\
777\end{array}$ & $\begin{array}{l}854.366 \\
256.351\end{array}$ & 3.333 & .006 & $6-10,26^{+}$ \\
\hline $\begin{array}{l}\text { Sendikalara } \\
\text { Üye Olma } \\
\text { Nedenleri }\end{array}$ & $\begin{array}{l}\text { Gruplar arası } \\
\text { Gruplar içi } \\
\text { Toplam }\end{array}$ & $\begin{array}{l}49.68 \\
9129.89 \\
9179.58\end{array}$ & $\begin{array}{l}5 \\
772 \\
777\end{array}$ & $\begin{array}{l}9.938 \\
11.826\end{array}$ & .840 & .521 & \\
\hline $\begin{array}{l}\text { Sendikalara } \\
\text { Üye Olmama } \\
\text { Nedenleri }\end{array}$ & $\begin{array}{l}\text { Gruplar arası } \\
\text { Gruplar içi } \\
\text { Toplam }\end{array}$ & $\begin{array}{l}3147.97 \\
97913.24 \\
101061.22\end{array}$ & $\begin{array}{l}5 \\
772 \\
777\end{array}$ & $\begin{array}{l}629.594 \\
126.831\end{array}$ & 4.964 & .000 & $\begin{array}{c}6-10,26^{+} \\
21-25,26^{+}\end{array}$ \\
\hline $\begin{array}{l}\text { Sendika Seçimi } \\
\text { Etkileyen } \\
\text { Faktörler }\end{array}$ & $\begin{array}{l}\text { Gruplar arası } \\
\text { Gruplar içi } \\
\text { Toplam }\end{array}$ & $\begin{array}{l}74.67 \\
9378.29 \\
9452.96\end{array}$ & $\begin{array}{l}5 \\
772 \\
777\end{array}$ & $\begin{array}{l}14.934 \\
12.148\end{array}$ & 1.229 & .293 & \\
\hline $\begin{array}{l}\text { Sendikalardan } \\
\text { Beklentileri }\end{array}$ & $\begin{array}{l}\text { Gruplar arası } \\
\text { Gruplar içi } \\
\text { Toplam }\end{array}$ & $\begin{array}{l}167.70 \\
28140.77 \\
28308.47\end{array}$ & $\begin{array}{l}5 \\
772 \\
777\end{array}$ & $\begin{array}{l}33.541 \\
36.452\end{array}$ & .920 & .467 & \\
\hline
\end{tabular}

Tablo 7. Öğretmenlerin Meslekî Örgütlenmeye İlişkin Görüşlerinin Yaşlarına Göre Değişimi

\begin{tabular}{|c|c|c|c|c|c|c|c|}
\hline Boyutlar & $\begin{array}{l}\text { Varyansın } \\
\text { Kaynağı }\end{array}$ & $\begin{array}{l}\text { Kareler } \\
\text { Toplamı }\end{array}$ & Sd & $\begin{array}{l}\text { Kareler } \\
\text { Ortalaması }\end{array}$ & $\mathbf{F}$ & $p$ & Fark \\
\hline Genel Boyut & $\begin{array}{l}\text { Gruplar aras1 } \\
\text { Gruplar içi } \\
\text { Toplam }\end{array}$ & $\begin{array}{l}2277.36 \\
199897.19 \\
202174.56\end{array}$ & $\begin{array}{l}3 \\
774 \\
777\end{array}$ & $\begin{array}{l}759.122 \\
258.265\end{array}$ & 2.939 & .032 & $1-40.51^{+}$ \\
\hline $\begin{array}{l}\text { Sendikalara } \\
\text { Üye Olma } \\
\text { Nedenleri }\end{array}$ & $\begin{array}{l}\text { Gruplar aras1 } \\
\text { Gruplar içi } \\
\text { Toplam }\end{array}$ & $\begin{array}{l}62.28 \\
9117.29 \\
9179.58\end{array}$ & $\begin{array}{l}3 \\
774 \\
777\end{array}$ & $\begin{array}{l}20.762 \\
11.779\end{array}$ & 1.763 & .153 & \\
\hline $\begin{array}{l}\text { Sendikalara } \\
\text { Üye Olmama } \\
\text { Nedenleri }\end{array}$ & $\begin{array}{l}\text { Gruplar aras1 } \\
\text { Gruplar içi } \\
\text { Toplam }\end{array}$ & $\begin{array}{l}1650.05 \\
99411.16 \\
101061.22\end{array}$ & $\begin{array}{l}3 \\
774 \\
777\end{array}$ & $\begin{array}{l}550.019 \\
128.438\end{array}$ & 4.282 & .005 & $\begin{array}{l}\mid-30.51^{+} \\
\mid-40.51^{+}\end{array}$ \\
\hline $\begin{array}{l}\text { Sendika Seçimi } \\
\text { Etkileyen } \\
\text { Faktörler }\end{array}$ & $\begin{array}{l}\text { Gruplar aras1 } \\
\text { Gruplar içi } \\
\text { Toplam }\end{array}$ & $\begin{array}{l}62.00 \\
9390.95 \\
9452.96\end{array}$ & $\begin{array}{l}3 \\
774 \\
777\end{array}$ & $\begin{array}{l}20.669 \\
12.133\end{array}$ & 1.704 & .165 & \\
\hline $\begin{array}{l}\text { Sendikalardan } \\
\text { Beklentileri }\end{array}$ & $\begin{array}{l}\text { Gruplar aras1 } \\
\text { Gruplar içi } \\
\text { Toplam }\end{array}$ & $\begin{array}{l}185.82 \\
28122.64 \\
28308.47\end{array}$ & $\begin{array}{l}3 \\
774 \\
777\end{array}$ & $\begin{array}{l}61.942 \\
36.334\end{array}$ & 1.705 & .165 & \\
\hline
\end{tabular}

Tablo 7'de yapılan tek yönlü varyans analizi sonucunda öğretmenlerin meslekî örgütlenmeye ilişkin görüşleri ile yaşları arasında anlamlı bir fark olduğu görülmektedir $[\mathrm{F}(3.774)=2.939, p<.05]$. Bu görüş farklılığının hangi gruplar arasında olduğunu belirlemek amacıyla yapılan Scheffe Testi sonuçlarına göre 31-40 yaş aralığındaki öğretmenler $(\overline{\mathrm{x}}=139.20, \mathrm{~S}=14.84), 51$ ve üstü yaş aralığındaki öğretmenlerden $(\overline{\mathrm{x}}=133.75, \mathrm{~S}=16.77)$ daha olumlu 
tutuma sahiptir. Öğretmenlerin sendikaya üye olma nedenleri boyutunda anlamlı bir farklıl1k görülmemektedir $\mathrm{F}(3.774)=1.763, p>.05$. Sendikalara üye olmama boyutunda ise anlamlı farklılık çıkmış $\mathrm{F}(3.774)=1.763, p<.05$, bu farklılığı belirlemek amaciyla yapılan Scheffe Testi sonucunda 21-30 yaş aralığındaki öğretmenler ( $\bar{x}=56.15, S=10.74), 51$ ve üstü yaş aralığındaki öğretmenlerden $(\overline{\mathrm{x}}=51.08, \mathrm{~S}=12.37)$ daha olumlu tutuma sahip oldukları ortaya çıkmıştır. Ayrıca 31-40 yaş aralığındaki öğretmenler $(\overline{\mathrm{x}}=55.37, \mathrm{~S}=10.93), 51$ ve üstü yaş aralığındaki öğretmenlerden ( $\overline{\mathrm{x}}=51,08, \mathrm{~S}=10.93)$ daha olumlu tutuma sahiptirler. Diğer yandan öğretmenlerin sendika seçimini etkileyen faktörler $\mathrm{F}(3.774)=1.704, p>.05$. ve sendikalardan beklentileri boyutunda anlamlı bir farkl111k görülmemektedir $[\mathrm{F}(3.774)=1.705, p>.05]$.

Tablo 8. Öğretmenlerin Branşlarına Göre Meslekî Örgütlenme ile İlgili Görüşlerinin Dağılımı

\begin{tabular}{llllllll}
\hline Boyutlar & $\begin{array}{l}\text { Varyansın } \\
\text { Kaynağı }\end{array}$ & $\begin{array}{l}\text { Kareler } \\
\text { Toplamı }\end{array}$ & Sd & $\begin{array}{l}\text { Kareler } \\
\text { Ortalaması }\end{array}$ & F & P & Fark \\
\hline Genel Boyut & Gruplar arası & 4043.550 & 16 & 252.722 & .971 & .487 \\
& Gruplar içi & 198131.013 & 761 & 260.356 & & \\
& Toplam & 202174.563 & 777 & & & \\
\hline Sendikalara & Gruplar arası & 309.208 & 16 & 19.326 & 1.658 & .050 \\
Üye Olma & Gruplar içi & 8870.372 & 761 & 11.656 & & \\
Nedenleri & Toplam & 9179.580 & 777 & & & \\
\hline Sendikalara & Gruplar arası & 3319.454 & 16 & 207.466 & 1.615 & .059 \\
Üye Olmama & Gruplar içi & 97741.766 & 761 & 128.439 & & \\
Nedenleri & Toplam & 101061.220 & 777 & & & .673 & .601 \\
\hline Sendika Seçimi & Gruplar arasi & 170.348 & 16 & 10.647 & & \\
Etkileyen & Gruplar içi & 9282.613 & 761 & 12.198 & & \\
Faktörler & Toplam & 9452.961 & 777 & & & & \\
\hline Sendikalardan & Gruplar arası & 739.782 & 16 & 46.236 & 1.276 & .205 \\
Beklentileri & Gruplar içi & 27568.692 & 761 & 36.227 & & \\
\hline & Toplam & 28308.474 & 777 & & & &
\end{tabular}

Tablo 8'de görüldüğü gibi yapılan tek yönlü varyans analizi sonucunda öğretmenlerin meslekî örgütlenmeye ilişkin görüşleri ile branşları arasında anlamlı bir fark olmadı ̆̆ 1 ortaya çıkmıştır [F(16.761)=.971, $p>.05]$. Öğretmenlerin sendikaya üye olma nedenleri boyutunda ise anlamlı bir farklılık görülmektedir $[\mathrm{F}(16.761)=1.658, p>.05]$. Ancak öğretmenlerin sendikaya üye olmama nedenleri $[\mathrm{F}(16.761)=1.615, p>.05]$ ve sendika seçimini etkileyen faktörler $[\mathrm{F}(16.761)=.873, p>.05]$ ve sendikalardan beklentileri boyutlarında anlamlı bir farklılık görülmemektedir $[\mathrm{F}(16.761)=1.276, p>.05]$.

Tablo 9'da yapılan tek yönlü varyans analizi sonucunda öğretmenlerin meslekî örgütlenmeye ilişkin görüşleri ile görev yaptıkları okul türleri arasında anlamlı bir fark olmadığ görülmektedir [F(3.774)=.966, $p>.05]$. 
Öğretmenlerin görev yaptıkları okul türüne göre sendikalara üye olma nedenleri $[\mathrm{F}(3.774)=1.302, \quad p>.05], \quad$ sendikalara üye olmama nedenleri $[\mathrm{F}(3.774)=.786, p>.05]$, sendika seçimini etkileyen faktörler $[\mathrm{F}(3.774)=.952$, $p>.05]$ ve sendikalardan beklentileri boyutlarında $[\mathrm{F}(3.774)=1.415, p>.05]$ anlamlı farklılık görülmemektedir.

Tablo 9. Öğretmenlerin Okul Türlerine Göre Meslekî Örgütlenme ile İlgili Görüşlerinin Dağılımı

\begin{tabular}{|c|c|c|c|c|c|c|c|}
\hline Boyutlar & $\begin{array}{l}\text { Varyansın } \\
\text { Kaynağı }\end{array}$ & $\begin{array}{l}\text { Kareler } \\
\text { Toplamı }\end{array}$ & Sd & $\begin{array}{l}\text { Kareler } \\
\text { Ortalaması }\end{array}$ & F & $P$ & Fark \\
\hline Genel Boyut & $\begin{array}{l}\text { Gruplar arası } \\
\text { Gruplar içi } \\
\text { Toplam }\end{array}$ & $\begin{array}{l}753.978 \\
201420.585 \\
202174.563\end{array}$ & $\begin{array}{l}3 \\
774 \\
777\end{array}$ & $\begin{array}{l}251.326 \\
260.233\end{array}$ & .966 & .408 & \\
\hline $\begin{array}{l}\text { Sendikalara Üye } \\
\text { Olma Nedenleri }\end{array}$ & $\begin{array}{l}\text { Gruplar arası } \\
\text { Gruplar içi } \\
\text { Toplam }\end{array}$ & $\begin{array}{l}46.105 \\
9133.475 \\
9179.580\end{array}$ & $\begin{array}{l}3 \\
774 \\
777\end{array}$ & $\begin{array}{l}15.368 \\
11.800\end{array}$ & 1.302 & .272 & \\
\hline $\begin{array}{l}\text { Sendikalara Üye } \\
\text { Olmama } \\
\text { Nedenleri }\end{array}$ & $\begin{array}{l}\text { Gruplar arası } \\
\text { Gruplar içi } \\
\text { Toplam }\end{array}$ & $\begin{array}{l}306.847 \\
100754.373 \\
101061.220\end{array}$ & $\begin{array}{l}3 \\
774 \\
777\end{array}$ & $\begin{array}{l}102.282 \\
130.174\end{array}$ & .786 & .502 & \\
\hline $\begin{array}{l}\text { Sendika Seçimi } \\
\text { Etkileyen } \\
\text { Faktörler }\end{array}$ & $\begin{array}{l}\text { Gruplar arası } \\
\text { Gruplar içi } \\
\text { Toplam }\end{array}$ & $\begin{array}{l}34.759 \\
9418.202 \\
9452.961\end{array}$ & $\begin{array}{l}3 \\
774 \\
777\end{array}$ & $\begin{array}{l}11.586 \\
12.168\end{array}$ & .952 & .415 & \\
\hline $\begin{array}{l}\text { Sendikalardan } \\
\text { Beklentileri }\end{array}$ & $\begin{array}{l}\text { Gruplar arası } \\
\text { Gruplar içi } \\
\text { Toplam } \\
\end{array}$ & $\begin{array}{l}154.391 \\
28154.083 \\
28308.474 \\
\end{array}$ & $\begin{array}{l}3 \\
774 \\
777 \\
\end{array}$ & $\begin{array}{l}51.464 \\
36.375\end{array}$ & 1.415 & .237 & \\
\hline
\end{tabular}

Tablo 10. Öğretmenlerin Görev Yerlerine Göre Meslekî Örgütlenme ile İlgili Görüşlerinin Dağ 11 ımı

\begin{tabular}{|c|c|c|c|c|c|c|c|}
\hline Boyutlar & $\begin{array}{l}\text { Varyansın } \\
\text { Kaynağı }\end{array}$ & $\begin{array}{l}\text { Kareler } \\
\text { Toplamı }\end{array}$ & Sd & $\begin{array}{l}\text { Kareler } \\
\text { Ortalaması }\end{array}$ & F & $p$ & Fark \\
\hline Genel Boyut & $\begin{array}{l}\text { Gruplar aras1 } \\
\text { Gruplar içi } \\
\text { Toplam }\end{array}$ & $\begin{array}{l}1280.87 \\
200893.68 \\
202174.56\end{array}$ & $\begin{array}{l}2 \\
775 \\
777\end{array}$ & $\begin{array}{l}640.439 \\
259.218\end{array}$ & 2.471 & .085 & \\
\hline $\begin{array}{l}\text { Sendikalara Üye } \\
\text { Olma Nedenleri }\end{array}$ & $\begin{array}{l}\text { Gruplar aras1 } \\
\text { Gruplar içi } \\
\text { Toplam }\end{array}$ & $\begin{array}{l}18.88 \\
9160.70 \\
9179.58\end{array}$ & $\begin{array}{l}2 \\
775 \\
777\end{array}$ & $\begin{array}{l}9.440 \\
11.820\end{array}$ & .799 & .450 & \\
\hline $\begin{array}{l}\text { Sendikalara Üye } \\
\text { Olmama } \\
\text { Nedenleri }\end{array}$ & $\begin{array}{l}\text { Gruplar aras1 } \\
\text { Gruplar içi } \\
\text { Toplam }\end{array}$ & $\begin{array}{l}582.94 \\
100478.27 \\
101061.22\end{array}$ & $\begin{array}{l}2 \\
775 \\
777\end{array}$ & $\begin{array}{l}291.472 \\
129.649\end{array}$ & 2.248 & .106 & \\
\hline $\begin{array}{l}\text { Sendika Seçimi } \\
\text { Etkileyen } \\
\text { Faktörler }\end{array}$ & $\begin{array}{l}\text { Gruplar aras1 } \\
\text { Gruplar içi } \\
\text { Toplam }\end{array}$ & $\begin{array}{l}42.67 \\
9410.28 \\
9452.96\end{array}$ & $\begin{array}{l}2 \\
775 \\
777\end{array}$ & $\begin{array}{l}21.338 \\
12.142\end{array}$ & 1.757 & .173 & \\
\hline $\begin{array}{l}\text { Sendikalardan } \\
\text { Beklentileri }\end{array}$ & $\begin{array}{l}\text { Gruplar aras1 } \\
\text { Gruplar içi } \\
\text { Toplam }\end{array}$ & $\begin{array}{l}230.55 \\
28077.92 \\
28308.47\end{array}$ & $\begin{array}{l}2 \\
775 \\
777\end{array}$ & $\begin{array}{l}115.277 \\
36.230\end{array}$ & 3.182 & .042 & $\begin{array}{l}\text { Belde, } \\
\text { köy, } \\
\text { il merkezi }\end{array}$ \\
\hline
\end{tabular}

Tablo 10'da yapılan tek yönlü varyans analizi sonucunda öğretmenlerin meslekî örgütlenmeye ilişkin görüşleri ile görev yaptıkları yerleri arasında anlamlı bir fark olmadığ 1 görülmektedir $[\mathrm{F}(2.775)=2.471, p>.05]$. Yine aynı 
şekilde öğretmenlerin görev yaptıkları yere göre sendikalara üye olma nedenleri $[\mathrm{F}(2.775)=1.799, \quad p>.05], \quad$ sendikalara üye olmama nedenleri $[\mathrm{F}(2.775)=2.248, p>.05]$ ve sendika seçimini etkileyen faktörler boyutlarında $[\mathrm{F}(2.775)=1.757, p>.05]$ anlamlı farkl1lık görülmemektedir. Ancak öğretmenlerin sendikalardan beklentileri boyutunda $[\mathrm{F}(2.775)=3.182, p<.05]$ anlaml farklı1ık görülmektedir. Bu görüş farklılığının hangi gruplar arasında olduğunu belirlemek amaciyla yapılan Scheffe Testi sonuçlarına göre il merkezinde görev yapan öğretmenler ( $\overline{\mathrm{X}}=44.25, \mathrm{~S}=5.80)$, belde-köy merkezinde görev yapan öğretmenlerden $[(\overline{\mathrm{X}}=42.40, \mathrm{~S}=5.85)]$ daha olumlu tutuma sahiptirler.

Tablo 11. Öğretmenlerin Sendika Üyeliğine İlişkin Meslekî Örgütlenme Görüşlerinin Dağılımı

\begin{tabular}{|c|c|c|c|c|c|c|c|}
\hline Boyutlar & Sendika & $\mathbf{N}$ & $\mathbf{X}$ & $\mathbf{S}$ & sd & $\mathbf{t}$ & $p$ \\
\hline \multirow{3}{*}{ Genel Boyut } & Evet & 636 & 137.02 & 15.52306 & \multirow[t]{3}{*}{776} & \multirow[t]{3}{*}{3.658} & \multirow[t]{3}{*}{.000} \\
\hline & Hayır & 142 & 142.46 & 18.00984 & & & \\
\hline & Toplam & 778 & 138.01 & & & & \\
\hline Sendikalara & Evet & 636 & 22.88 & 3.04048 & \multirow[t]{3}{*}{776} & \multirow[t]{3}{*}{6.078} & \multirow[t]{3}{*}{.000} \\
\hline Üye Olma & Hayır & 142 & 20.99 & 4.52897 & & & \\
\hline Nedenleri & Toplam & 778 & 22.54 & & & & \\
\hline Sendikalara & Evet & 636 & 53.28 & 10.96355 & \multirow[t]{3}{*}{776} & \multirow[t]{3}{*}{7.332} & \multirow[t]{3}{*}{.000} \\
\hline Üye Olmama & Hayır & 142 & 60.79 & 11.35700 & & & \\
\hline Nedenleri & Toplam & 778 & 54.65 & & & & \\
\hline Sendika Seçimi & Evet & 636 & 16.88 & 3.42888 & \multirow[t]{3}{*}{776} & \multirow[t]{3}{*}{1.085} & \multirow[t]{3}{*}{.278} \\
\hline Etkileyen & Hayır & 142 & 17.2409 & 3.74055 & & & \\
\hline Faktörler & Toplam & 778 & 16.95 & & & & \\
\hline Sendikalardan & Evet & 636 & 43.96 & 5.99102 & \multirow[t]{3}{*}{776} & \multirow[t]{3}{*}{.950} & \multirow[t]{3}{*}{.342} \\
\hline \multirow[t]{2}{*}{ Beklentileri } & Hayır & 142 & 43.43 & 6.23646 & & & \\
\hline & Toplam & 778 & 43.87 & & & & \\
\hline
\end{tabular}

Tablo 11'de, öğretmenlerin meslekî örgütlenmeleri ile ilgili görüşlerinin sendika üyesi olup almama durumlarına göre yapılan bağımsız $t$ Testi sonuçları incelendiğinde genel boyutta anlamlı bir farklılık görülmektedir $[\mathrm{t}(776)=3.658, p<.05]$. Bu bulgudan hareketle sendika üyesi olmayan öğretmenlerin ( $\bar{x}=142.46)$, sendika üyesi olan öğretmenlerden $(\bar{x}=137.02)$ daha olumlu tutuma sahip oldukları söylenebilir. Öğretmenlerin sendika üyesi olma nedenleri boyutu incelendiğinde, sendika üyesi olan öğretmenlerin lehine anlamlı farklılık olduğu görülmektedir $[\mathrm{t}(776)=6.078, p<.05]$. Bu bulgudan sendika üyesi olan öğretmenlerin ( $\overline{\mathrm{x}}=22,88)$, sendika üyesi olmayan öğretmenlerden $(\bar{x}=20,99)$ daha olumlu tutuma sahip oldukları söylenebilir. Öğretmenlerin sendika üyesi olmama nedenleri boyutu incelendiğinde, sendika üyesi olmayan öğretmenlerin lehine anlamlı farklılık olduğu görülmektedir $[\mathrm{t}(776)=7.332, p<.05]$. Sendika üyesi olmayan öğretmenler $(\bar{x}=60.79)$, 
sendika üyesi olan öğretmenlerden $(\overline{\mathrm{x}}=53.28)$ daha olumlu tutuma sahip oldukları söylenebilir. Öğretmenlerin sendika seçimini etkileyen faktörler $[\mathrm{t}(776)=1.085, p>.05]$ ve sendikalardan beklentileri boyutlarında öğretmenlerin örgütlenme ile ilgili tutumlarında anlamlı bir farklılık görülmemektedir $[\mathrm{t}(776)=.950, p>.0]$.

Tablo 12. Öğretmenlerin Görüşlerinin Sendika Üyelik Sürelerine Göre Değişimi

\begin{tabular}{|c|c|c|c|c|c|c|c|}
\hline Boyut & $\begin{array}{l}\text { Varyansı } \\
\text { Kaynağı }\end{array}$ & $\begin{array}{l}\text { Kareler } \\
\text { Toplamı }\end{array}$ & Sd & $\begin{array}{l}\text { Kareler } \\
\text { Ortalaması }\end{array}$ & $\mathbf{F}$ & $P$ & Fark \\
\hline Genel Boyut & $\begin{array}{l}\text { Gruplar arası } \\
\text { Gruplar içi } \\
\text { Toplam }\end{array}$ & $\begin{array}{l}5483.90 \\
196690.66 \\
202174.56\end{array}$ & $\begin{array}{l}4 \\
773 \\
777\end{array}$ & $\begin{array}{l}1370.976 \\
254.451\end{array}$ & 5.388 & .000 & Üye olm $/ 15^{+}$ \\
\hline 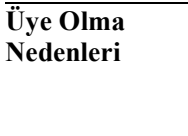 & $\begin{array}{l}\text { Gruplar aras1 } \\
\text { Gruplar içi } \\
\text { Toplam }\end{array}$ & $\begin{array}{l}506.26 \\
8673.31 \\
9179.58\end{array}$ & $\begin{array}{l}4 \\
773 \\
777\end{array}$ & $\begin{array}{l}126.567 \\
11.220\end{array}$ & 11.282 & .000 & 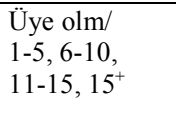 \\
\hline 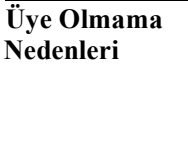 & $\begin{array}{l}\text { Gruplar arası } \\
\text { Gruplar içi } \\
\text { Toplam }\end{array}$ & $\begin{array}{l}9455642 \\
91605.57 \\
101061.22\end{array}$ & $\begin{array}{l}4 \\
773 \\
777\end{array}$ & $\begin{array}{l}2363.911 \\
118.507\end{array}$ & 19.948 & .000 & $\begin{array}{l}\text { Üye olm } / 1-5, \\
6-10,11-15,15^{+} \\
1-5 / 15^{+} \\
6-10 / 15^{+}\end{array}$ \\
\hline $\begin{array}{l}\text { Sendika Seçi- } \\
\text { mini Etkileyen } \\
\text { Faktörler }\end{array}$ & $\begin{array}{l}\text { Gruplar arası } \\
\text { Gruplar içi } \\
\text { Toplam }\end{array}$ & $\begin{array}{l}82.52 \\
9370.43 \\
9452.96\end{array}$ & $\begin{array}{l}4 \\
773 \\
777\end{array}$ & $\begin{array}{l}20.631 \\
12.122\end{array}$ & 1.702 & .148 & \\
\hline $\begin{array}{l}\text { Sendikalardan } \\
\text { Beklentileri }\end{array}$ & $\begin{array}{l}\text { Gruplar arası } \\
\text { Gruplar içi } \\
\text { Toplam }\end{array}$ & $\begin{array}{l}45.51 \\
28262.95 \\
28308.47 \\
\end{array}$ & $\begin{array}{l}4 \\
773 \\
777 \\
\end{array}$ & $\begin{array}{l}11.379 \\
36.563\end{array}$ & .311 & .871 & \\
\hline
\end{tabular}

Tablo 12'de, yapılan tek yönlü varyans analizi sonucunda öğretmenlerin meslekî örgütlenme ile ilgili genel görüşleri öğretmenlerin sendikalara üyelik sürelerine göre anlamlı farkl1lık olduğu görülmektedir $[\mathrm{F}(4.773)=5.388, p<.05]$. Bu görüş farklılı̆̆ının hangi gruplar arasında olduğunu belirlemek amacıyla yapılan Scheffe Testi sonuçlarında, sendikalara üye olmayan öğretmenler ( $\overline{\mathrm{x}}=142.46, \mathrm{~s}=18.00)$ ile 15 ve üstü yıl sendikalı öğretmenlerden $(\overline{\mathrm{x}}=134.25, \mathrm{~s}=17.00)$ daha olumlu tutuma sahiptirler. Öğretmenlerin örgütlenme ile ilgili görüşleri sendikalara üye olma nedenleri boyutunda anlamlı farkl11ık olduğu görülmektedir $[\mathrm{F}(4.773)=11.282, p<.05]$. Bu görüş farklılığının hangi gruplar arasında olduğunu belirlemek amacıyla yapılan Scheffe Testi sonuçlarında, sendika üyesi olan tüm gruplardaki öğretmenler sendika üyesi olmayan öğretmenlerin görüşlerinden anlamlı olarak farklılaştığı görülmüştür. Buna göre; $1-5$ yıldır sendikalı olan öğretmenlerin $(\overline{\mathrm{x}}=22.49$, $\mathrm{s}=3.01), 6-10$ yıldır üye olan öğretmenlerin $(\overline{\mathrm{x}}=22.81, \mathrm{~s}=2.96), 11-14$ y1ldır üye olan öğretmenlerin $(\overline{\mathrm{x}}=22.90, \mathrm{~s}=3.28), 15$ ve üstü yıldır üye olan öğretmenlerin $(\overline{\mathrm{x}}=23.44, \mathrm{~s}=2.93)$ üye olmayan öğretmenlerden $(\overline{\mathrm{x}}=20.99, \mathrm{~s}=4.52)$ 
daha olumlu tutuma sahip oldukları söylenebilir. Yine öğretmenlerin örgütlenme ile ilgili görüşleri sendikalara üye olmama nedenleri boyutunda anlamlı farklı1ık olduğu görülmektedir [F(4.773)=19.498, $p<.05]$. Bu görüş farklılığ1nın hangi gruplar arasında olduğunu belirlemek amaciyla yapılan Scheffe Testi sonuçlarına göre sendika üyesi olmayan öğretmenlerin görüşleri, sendika üyesi olan tüm gruplardaki öğretmenlerin görüşlerinden anlamlı olarak farklılaştığı görülmüştür. Herhangi bir sendikaya üye olmayan öğretmenler $(\overline{\mathrm{x}}=60.79, \mathrm{~s}=11.35), 1-5$ yıldır üye olan öğretmenlerden $(\overline{\mathrm{x}}=55.31, \mathrm{~s}=10.09)$, 6-10 yıldır üye olan öğretmenlerden ( $(\bar{x}=54.12, \mathrm{~s}=9.79), 11-14$ yıldır sendikalı öğretmenlerden ( $\overline{\mathrm{x}}=53.21, \mathrm{~s}=11.46)$ ve 15 ve üstü yıldır sendikalı olan öğretmenlerden $(\bar{x}=50.01, s=11.95)$ daha olumlu tutuma sahip oldukları ortaya çıkmıştır. Bununla birlikte Scheffe Testi sonucunda 1-5 yıldır üye olan öğretmenlerin $(\overline{\mathrm{x}}=55.31, \mathrm{~s}=10.09), 15$ ve üstü yıldır sendikalı olan öğretmenlerden $(\overline{\mathrm{x}}=50.01, \mathrm{~s}=11.95)$ daha olumlu tutuma sahip oldukları görülmektedir. 6-10 yıldır üye olan öğretmenlerin ( $\overline{\mathrm{x}}=54.12, \mathrm{~s}=9.79), 15$ ve üstü yıldır sendikalı olan öğretmenlerden ( $\bar{x}=50.01, \mathrm{~s}=11.95)$ daha olumlu tutuma sahip oldukları görülmektedir. Öğretmenlerin örgütlenme ile ilgili görüşleri sendika seçimi etkileyen faktörler boyutunda $[\mathrm{F}(4.773)=1.702, p>.05]$ ve sendikalardan beklentileri boyutunda anlamlı farklılık olmadığ görülmektedir $[\mathrm{F}(4.773)=.311$, $p>.05]$.

Tablo 13. Öğretmenlerin Sendika Değişikliğine Göre Görüşlerinin Dağılımı

\begin{tabular}{|c|c|c|c|c|c|c|c|}
\hline Boyutlar & Değișiklik & $\mathbf{N}$ & $\mathbf{X}$ & $\mathbf{S}$ & sd & $\mathbf{t}$ & $p$ \\
\hline \multirow[t]{3}{*}{ Genel Boyut } & Evet & 280 & 138.8726 & 14.006 & \multirow[t]{3}{*}{776} & \multirow[t]{3}{*}{1.108} & \multirow[t]{3}{*}{.268} \\
\hline & Hayır & 498 & 137.5380 & 17.204 & & & \\
\hline & Toplam & 778 & 138.01 & & & & \\
\hline \multirow{3}{*}{$\begin{array}{l}\text { Sendikalara } \\
\text { Üye Olma } \\
\text { Nedenleri }\end{array}$} & Evet & 280 & 22.8738 & 3.075 & \multirow[t]{3}{*}{776} & \multirow[t]{3}{*}{2.034} & \multirow[t]{3}{*}{.042} \\
\hline & Hayır & 498 & 22.3525 & 3.614 & & & \\
\hline & Toplam & 778 & 22.54 & & & & \\
\hline \multirow{3}{*}{$\begin{array}{l}\text { Sendikalara } \\
\text { Üye Olmama } \\
\text { Nedenleri }\end{array}$} & Evet & 280 & 54.8704 & 10.136 & \multirow[t]{3}{*}{776} & \multirow[t]{3}{*}{.399} & \multirow[t]{3}{*}{.690} \\
\hline & Hayır & 498 & 54.5306 & 12.067 & & & \\
\hline & Toplam & 778 & 54.65 & & & & \\
\hline \multirow{3}{*}{$\begin{array}{l}\text { Sendika Seçimi } \\
\text { Etkileyen } \\
\text { Faktörler }\end{array}$} & Evet & 280 & 17.2539 & 3.168 & \multirow[t]{3}{*}{776} & \multirow[t]{3}{*}{1.802} & \multirow[t]{3}{*}{.072} \\
\hline & Hayır & 498 & 16.7852 & 3.647 & & & \\
\hline & Toplam & 778 & 16.95 & & & & \\
\hline \multirow{3}{*}{$\begin{array}{l}\text { Sendikalardan } \\
\text { Beklentileri }\end{array}$} & Evet & 280 & 43.8746 & 5.828 & \multirow[t]{3}{*}{776} & \multirow[t]{3}{*}{.011} & \multirow[t]{3}{*}{.991} \\
\hline & Hayır & 498 & 43.8696 & 6.155 & & & \\
\hline & Toplam & 778 & 43.87 & & & & \\
\hline
\end{tabular}

Tablo 13'te öğretmenlerin meslekî örgütlenmeleri ile ilgili görüşlerinin sendika değişikliği yapıp yapmama durumlarına göre yapılan bağımsız $t$ Testi sonuçları incelendiğinde genel boyutta anlamlı bir farklılık görülmemektedir $[\mathrm{t}(776)=1.108, p>.05]$. Ancak öğretmenlerin meslekî örgütlenmeleri ile ilgili 
görüşleri sendikalara üye olma nedenleri boyutunda incelendiğinde anlamlı bir farkl11ık görülmektedir $\mathrm{t}(776)=2.034$. Bu bulgudan sendika değişikliği yapan öğretmenlerin $(\overline{\mathrm{x}}=22.87, \mathrm{~s}=3.075)$ sendika değişikliği yapmayan öğretmenlerden $(\overline{\mathrm{x}}=22.35, \mathrm{~s}=3.614)$ daha olumlu tutuma sahip oldukları söylenebilir. Aynı şekilde öğretmenlerin meslekî örgütlenmeleri ile ilgili görüşleri sendikalara üye olmama nedenleri boyutunda $\mathrm{t}(776)=.399$, sendika seçimini etkileyen faktörler boyutunda $t(776)=1.802$ ve sendikalardan beklentileri boyutunda anlamlı bir farkl1lık görülmemektedir t (776)=.011.

Diğer yandan öğretmenlerin son zamanlarda sendika değiştirme veya değiştirmeme nedenlerine ilişkin yarı yapılandırılmış açık uçlu soru ile toplan verilerin değerlendirilmesi aşağıdaki tablolarda yer almaktadır.

Tablo 14. Öğretmenlerin Sendika Değiştirme Nedenlerine İlişskin Görüşleri

\begin{tabular}{llll}
\hline Politik Nedenler (f:54) & Yetersizlik (f:37) & $\begin{array}{l}\text { Yönetici ve Üye } \\
\text { Kaynaklı (f:18) }\end{array}$ & Çevre (f:2) \\
\hline Fikir ayr1lıkları (f:31) & Hizmet yetersizliği (f:13) & Genel merkez(f:10) & Arkadaş etkisi (f:2) \\
Politik söylemleri (f:12) & Temsil edememe (f:9) & Yerel yönetici(f:6) & \\
Siyasi Sapmalar (f:11) & Güvensizlik (f:8) & Üyeler kaynaklı(f:2) & \\
& Sorumsuzluk (f:7) & & \\
\hline
\end{tabular}

Tablo 14'te görüldüğü gibi öğretmenlerin sendika değiştirme nedenlerine bakıldığında fikir ayrılıkları olduğu anlaşılmaktadır. Aşağıdaki ifadeler ise politik boyuttaki öğretmen görüşlerine örnek olarak verilebilir:

"Fikir uyuşmazlığı, sendikalar öğretmen hakkını savunmaktan çok siyasetle uğraşmalarından dolayı sendika değiştirdim." (Ö50)

"Sendikalar şahsi menfaatler çerçevesinde çalıştığ için ve siyasallaştığı için değiştirdim." (Ö48)

"Sendikanın tasvip etmediğim çevrelere vermiş olduğu destek nedeniyle değiştirdim." (Ö563)

"Sendikayla görüşlerimizin uyuşmaması ve görüşlerimize uygun bir sendika kurulması nedeniyle sendika değiştirdim.” (Ö67)

Öğretmenlerin sendika değiştirme nedenleri olarak (f:13) ikinci sırada hizmet yetersizliğini ileri sürdükleri görülmektedir. Yetersizlik boyutunda öğretmen görüşleriyle ilgili örnekler aşağıdaki şekildedir:

"Önceki sendikamin sadece üye yapana kadar tanımast, ondan sonra herhangi bir durumda yardımcı olmaması nedeniyle sendikamdan ayrıldım." (Ö420)

"Öğretmenlerin sendikalaştırılarak ayrıştırıldığını düşünüyorum. Ancak sendikalı olmazsak da haklarımızı savunamıyoruz. Dolaylsıyla sendikamı haklarımı savunmadığı için değiş̧tirdim." (Ö356)

"Yeni sendikamın daha etkin çalışmalar yaptığını düşündüğüm için sendikamdan ayrlldım." (Ö738) 
"Sendikamın söylemlerinin birbirini tutmaması sebebiyle sendikamdan ayrildım." (Ö76)

Tablo 14'te öğretmenlerin sendika değiştirme nedenlerine bakıldığında yönetici ve üyelerden kaynaklı olduğu görülmektedir. Bunlara ilişkin öğretmen görüşlerine örnekler şöyledir:

"Sendika yöneticilerinin kendi çıkarları doğrultusunda iş yapmaları nedeniyle ayrıldım." (Ö474)

"Yeni istifa ettim ama henüz cevap gelmedi. Sendikanın fikirleriyle ters düşı̈̈̆üumü anladım. Sebebi de şu sendika yönetimindekilerin birleştirici değil ayrıştırıcı olması bunda etkili oldu." (Ö794)

"Sendika üyelerinin tutum ve davranışları sebebiyle sendika değiştirdim." (Ö332)

"Sendikanın yönetim kadrosunun düşüncelerinin farklılaşması sebebiyle sendika değiştirdim.” (Ö354)

Tablo 13'te öğretmenlerin sendika değiştirme nedenlerine bakıldığında çevre boyutunda yer aldı̆̆ı görülmektedir. Çevre boyutunda yer alan öğretmen görüşlerine örnekler şu şekildedir: "Arkadaş hatırı için sendikadan ayrıldım." (Ö246) "Arkadaş isteği için sendikamdan ayrıldım." (Ö146).

Tablo 15. Sendika Değişikliği Yapmayan Öğretmenlerin Sendika Değiştirmeme Nedenlerine İlişkin Görüşleri

\begin{tabular}{ll}
\hline Yeterlik (f:49) & Politik Nedenler (f:6) \\
\hline Memnunum: 39 & Politik duruş: 3 \\
Sorumluluk: 6 & Görüş birliği: 3 \\
Güven: 7 & \\
Temsil edebilme: 4 & \\
\hline
\end{tabular}

Tablo 15'te sendika değişikliği yapmayan öğretmenlerin sendika değiştirmeme nedenlerine bakıldığında yeterlilik (f:49) meselesinin birinci derecede etkili olduğu görülmektedir. Öğretmenlerin sendika değiştirmemeye ilişkin politik boyutta öğretmen görülerine ilişkin örnekler şu şekildedir:

"Dünya görüşüme uygun olduğu için ve çalışmalarına inandığım için."

(Ö85)

"Savunulan düşünceler ve ilkeler doğrultusunda sendika seçimi yapılmalı ve tutarlı olunmalı. Çıkar uğruna yapılan sendika değiş̧ikliğini kişiliksizlik olarak görüyorum." (Ö305)

"Kendime yakın olduğunu düşündüğümden dolayı." (Ö676)

"Sendikamın duruşunu beğeniyorum." (Ö749)

Sendika değişikliği yapmayan öğretmenlerin sendika değiştirmeme nedenlerine bakıldığında politik nedenlerin (f;6) ikinci derecede etkili olduğu 
görülmektedir. Buna yönelik öğretmen görüşlerine ilişkin örnekler aşağıdaki gibidir:

"Sendikacllık nedir, nasll yapılır en iyi şekilde gösterdiği için sendikamdan ayrilmam." (Ö614)

"Doğrunun yanında yanlışın karşısında olduğu için." (Ö412)

"Sosyal aksaklıklara daha duyarlı bir sendika olduğu için." (Ö61)

"Sendikamla ilgili olumsuzluk olmadıkça tercihimi kolay kolay değiştirmem." (Ö611)

"Sendikamin haklarımı koruduğuna inanıyorum." (Ö720)

\section{Sonuç ve Tartışma}

$\mathrm{Bu}$ çalışmada nicel olarak toplanan verilerin analizine göre öğretmenlerin \%81.7'sinin meslekî örgüt üyesi olduğu, \%18.3'ünün ise herhangi bir meslekî örgüte üye olmadığı sonucuna ulaşılmıştır. Ancak sendika üyesi olmayan öğretmenlerin (A.O=4.07), sendika üyesi olan öğretmenlere (A.O.=3.91) göre örgütlenmeye ilişkin daha olumlu görüşe sahip oldukları görülmektedir. Baysal, Türkmen ve Yücel'in (2010) yaptığı araştırmada öğretmenlerin \%58.6'sının meslekî bir örgüte üye olduğu bulgusuna, Tok'un (1996) yapmış olduğu araştırmada örgütlü öğretmen oranının \%39 olduğu bulgusuna ve Boyacı'nın (1994) yapmış olduğu çalışmada öğretmenlerin \%87'sinin örgütlenmeden yana olduğunu ancak örgütlü öğretmen oranının ise \%33.2 oranında olduğu bulgusuna ulaşılmıştır.

$\mathrm{Bu}$ çalışmada, erkek öğretmenlerin \%89.9'unun, kadın öğretmenlerin de \%71.9'unun sendika üyesi görülmektedir. Bununla birlikte erkek ve kadın öğretmenlerin örgütlenmeye yönelik tutumları arasında anlamlı bir farklılık görülmezken, erkek öğretmenler sendika üyesi olma nedenleri boyutunda, kadın ögretmenlere göre daha olumlu tutuma sahip oldukları sonucu ortaya çıkmıştır. Kadın öğretmenler ise sendikaya üye olmama nedenleri boyutunda erkek öğretmelere göre daha olumlu tutuma sahiptirler. Boyacı (1994) araştırmasında erkek öğretmenlerin örgütlenme oranının \%47, kadın öğretmenlerin örgütlenme oranının ise \%22 olduğu bulgusuna ulaşmıştır. Baysal, Türkmen ve Yücel (2010) ise araştırmalarında kadın öğretmenlerin \%61.2'sinin, erkek öğretmenlerin ise \%29.9'unun herhangi bir meslekî örgütüne üye olmadığ sonucuna ulaşmıştır. Yapılan araştırmalar doğrultusunda gün geçtikçe öğretmenlerin sendikalaşma oranında artış olduğu söylenebilir. Bu artışın öğretmenlerin örgütlenmeleri ile ilgili yasal kolaylaştırmalar ve teşviklerden kaynaklandığı söylenebilir. 
$\mathrm{Bu}$ araştırmada, 6-10 yıl kıdeme sahip öğretmenlerin meslekî örgütlenme genel boyutunda, 26 yıl ve üstü kıdeme sahip olan öğretmenlerden daha olumlu görüşe sahip oldukları ortaya çıkmıştır. Ayrıca sendikaya üye olmama alt boyutunda 6-10 y1l kıdeme sahip öğretmenler, 26 yıl ve üstü kıdeme sahip öğretmenlerden daha olumlu, 21-25 y1l kıdeme sahip öğretmenler, 26 yıl ve üstü kıdeme sahip öğretmenlerden daha olumlu görüşe sahip oldukları sonucuna ulaşılmıştır. Baysal, Türkmen ve Yücel (2010), yapmış olduğu araştırmada 1-5 yıl ve 6-10 yıl kıdeme sahip öğretmenlerin meslekî örgütlenme genel boyutunda diğer kıdemlere göre daha olumlu görüsse sahip olduğu bulgusuna ulaşmıştır. Dolayısıyla bu sonuçtan öğretmenlerin meslekî kariyerlerinin sonlarında öğretmen örgütlenmesine yönelik olumsuz tutuma sahip oldukları söylenebilir.

Öğretmenlerin yaş durumlarına göre örgütlenme ile ilgili görüşleri incelendiğinde genel boyutta anlamlı farklılık görülmemiştir. Ancak 31-40 yaş grubunda bulunan öğretmenlerin örgütlenmeye yönelik görüşleri, 51 ve üstü yaş grubunda olanlardan daha olumludur. Bu bulgu araştırmada 6-10 y1l k1deme sahip öğretmenlerin meslekî örgütlenme genel boyutunda, 26 yıl ve üstü kıdeme sahip olan öğretmenlerden daha olumlu görüsşe sahip oldukları bulgusunu desteklemektedir.

Öğretmenlerin branş durumlarına göre örgütlenme ile ilgili görüşlerinde anlamlı bir farkl1lık görülmemiştir. Ancak genel boyutta meslek lisesi öğretmenlerinin din kültürü ve ahlak bilgisi öğretmenlerinden daha olumlu görüşe sahip oldukları sonucuna varılmıştır. Öğretmenlerin görev yaptığı okul türü durumlarına göre örgütlenme ile ilgili görüşlerinde anlamlı farklılık görülmemiştir. Ancak genel boyutta meslek liselerinde görev yapan öğretmenler, genel liselerde görev yapan öğretmenlerden daha olumlu görüşe sahip oldukları ortaya çıkmıştır. Ancak öğretmenlerin görev yaptığı yerleşim yeri durumlarına göre örgütlenmeyle ilgili görüşlerinde genel boyutta anlamlı farklı$11 \mathrm{k}$ çıkmamıştır. Ancak köy ve beldelerde göre yapan öğretmenlerin diğer yerleşim yerlerinde görev yapan öğretmenlerden daha olumsuz görüşe sahip oldukları görülmüştür. Sendikalardan beklentileri boyutunda öğretmen görüşlerinde anlamlı farklılıklar ortaya çıkmış ve il merkezinde görev yapan öğretmenlerin köy ve beldelerde görev yapan öğretmenlerden daha olumlu tutuma sahip oldukları sonucuna varılmıştır.

Öğretmenlerin mezuniyet durumlarına göre örgütlenme ile ilgili görüşlerinde anlamlı farkl111k görülmemiştir. Ancak hem genel boyutta hem de tüm 
alt boyutlarda fen edebiyat fakültesi mezunu öğretmenlerin diğer eğitim kurumlarından mezun öğretmenlerden daha olumlu görüsse sahip oldukları görülmüştür. Baysal, Türkmen ve Yücel (2010), lisans düzeyinde mezuniyete sahip olan öğretmenlerin eğitim enstitüsü ve eğitim yüksekokulundan mezun olan öğretmenlerden daha olumlu görüşe sahip olduğu bulgusuna ulaşmıştır.

Öğretmen görüşlerine göre ilginç bir bulgu olarak sendika üyesi olmayan öğretmenler sendika üyesi olan öğretmenlere göre daha olumlu tutuma sahiptir. Sendika üyesi olmayan öğretmenlerin sendika üyesi olan öğretmenlere göre örgütlenmeye yönelik daha olumlu görüşe sahip oldukları görülmüştür. Sendikaya üyelik sürelerine göre sendika üyesi olmayan öğretmenlerin, diğer yıl gruplarında bulunan öğretmenlere göre daha olumlu görüşe sahip olduğu tespit edilmiştir. Ancak sendikalılık süresi yükseldikçe öğretmenlerin örgütlenmeye yönelik görüş ortalamaları azalmaktadır. Öğretmenlerin meslekî örgütlenmeye yönelik görüşleri, sendika değişikliği yapmış olanların görüşleri, sendika değişikliği yapmamış olan öğretmenlere göre daha olumlu görüşe sahip oldukları sonucuna varılmıştır.

Yarı yapılandırılmış açık uçlu soru ile toplanan verilerin analizi ile elde edilen sonuçlara göre öğretmenlerin sendika değiştirme nedenlerine bakıld1ğında öğretmenlerin daha çok politik nedenler sebebiyle sendika değişikliği yaptıkları görülmektedir. Politik nedenler sebebiyle sendika değişikliği yapan öğretmenler daha çok fikir ayrılıklarından dolayı bağlı bulundukları sendikadan ayrılıp başka bir sendikaya üye olmuşlardır. Bu bulgu Ulutaş ve Sönmez'in (2011) araştırmasındaki gibi katılımcıların yarısından çoğunun siyasi görüşlerine göre sendika seçimi yaptığı bulgusuyla paralellik göstermektedir. Öğretmenlerin büyük bir çoğunluğu sendika değişim sebeplerini fikir ayrılıklarına bağlamıştır.

$\mathrm{Bu}$ araştırmada öğretmenlerin sendika değişimlerini etkileyen ikinci faktörünü sendikaların yetersizliği meselesi oluşturmaktadır. Bu sonuca göre öğretmenlerin sendikal olarak yeterlilik anlamında arayış içinde oldukları, kendilerini temsil edilebilecekleri, güvenebilecekleri, sorumluluk sahibi olarak yeterli hizmet verebilecek sendika arayışında oldukları söylenebilir. Ulutaş ve Sönmez (2011) araştırmalarında, katılımcıların sendikayı özlük haklarını koruyan en iyi kuruluş olarak gördüğü, ancak sendikaların örgütlenememesi ve temsil sorunu olduğu sonucuna ulaşmıştır.

Öğretmenlerin sendika değiştirme nedenleri arasında yöneticilerden ve diğer üyelerden kaynaklı sorunlar olduğu sonucu çıkarılabilir. Öğretmenler 
daha çok genel merkez ve yerel yöneticiler sebebiyle sendika değiştirdiklerini belirtmişlerdir. Taşdan (2013) öğretmenlerin büyük çoğunluğunun sendika yöneticilerinin yetersiz olduğunu ifade etmektedir. Sendikalı öğretmenlere göre bu yetersizliğin temel sebepleri ideolojilerini eğitimin faydasında kullanmamaları, insan ilişkileri konusunda başarısız olmaları, ikna etme kabiliyetlerinin yetersiz oluşu, bilgi eksiklikleri, üslup ve diyalog konularında eksik olmaları, ideolojik yaklaşımları ile gerekli donanıma sahip olmayışlarıdır. $\mathrm{Bu}$ çalışmada Taşdan'ın (2013) bulgularına paralel olarak öğretmenler, sendika yöneticilerinin ayrıştırıcı olduklarını, çıkarlarını ön plana yerleştirdiklerini, ideolojik olarak farklılaşma yaşadıklarını ve olumsuz tutum ve davranışlara maruz kaldıklarından dolayı sendika değişikliği yaptıklarını belirtmişlerdir.

Bu çalışmada, sendika değişikliği yapan öğretmenlerin siyasi görüş ve düşüncelerine göre sendika değişimi yaptıklarını ifade ederler iken, sendika değişikliği yapmayan öğretmenler ise; siyasi görüş ve düşüncelerinden çok sendika memnuniyeti ve sendikal yeterlilik sebebinden dolayı sendika değişikliği yapmadıklarını belirtmektedirler. Taşdan (2013) sendikalı öğretmenlerin genellikle mensubu oldukları sendikadaki faaliyetlerin siyasi görüş ve düşüncelerine uygun geldiği için bu oluşuma üye olduklarını söylediklerini ifade etmektedir.

Sendika değişikliği yapmayan öğretmenlerin sendika değiştirmeme nedenlerinde, daha çok kendi sendikalarının çalışmalarını yeterli buldukları görülmektedir. Gül (2007) ise çalışmasında öğretmenlerin çoğunluğunun sendikaların çalışmalarını yeterli görmedikleri için sendika değiş̧irdikleri sonucuna ulaşmıştır. Dolayısıyla bu bulgu, araştırmanın bulgusu ile farklılık göstermektedir. Sendika değiştirmeyen öğretmenler, bağlı bulundukları sendikanın çalışmalarını yeterli gördükleri, çalışmalarından daha çok memnun oldukları ve sendikalarına güven duyduklarını belirtmişlerdir.

$\mathrm{Bu}$ sonuçlara göre öğretmen örgütlenmelerinin başlı başına bir öğretmen sorunu olduğu ortaya çıkmaktadır. Bütün mesleklerde olduğu gibi öğretmenlik mesleğinde de öğretmen örgütleri bir mensubiyet bilincinin gelişmesi ve meslek saygınlığının oluşmasında önemli araçlardan biridir. Bu örgütler aracılığıyla ögretmenler meslekî alanlardaki çalışmaları takip ederek kişisel gelişimlerinin sağlanması yanında, sosyal ve hukuki statülerindeki iyileştirmelere de olumlu katkılarda bulunabilirler. Bu açılardan bakıldığında eğitim ve öğretmen sorunlarına odaklanmış öğretmen örgütlerine ihtiyaç olduğunu söylemek mümkündür. 


\section{Kaynaklar}

Akyüz, Y. (1978). Türkiye’de öğretmenlerin toplumsal değişmedeki etkileri (18481940). Ankara: Doğan Basımevi.

Akyüz, Y. (1980). Öğretmenlerin örgütlenmesi Türkiye, Fransa, İsviçre'de ve uluslararası düzeyde kuruluşlar, etkinlikler, sorunlar. Ankara: A.Ü.E.F Yayınları.

Akyüz, Y. (2012). Türk ĕgitim tarihi: M.Ö. 1000-M.S. 2012 (Genişletilmiş 8. basım). Ankara: Pegem Yayınevi.

Akyüz, Y. (2016). Türk eğitim tarihi M.Ö. 1000-M.S. 2016 (28. bask1). Ankara: Pegem Akademi Yayınları.

Altunya, N. (2008). Türkiye'de ögretmen örgütlenmesi, 1908-2008. Ankara: Ürün Yayınları.

Arslanoğlu, İ. (2018). Eğitim felsefesi (Geliştirilmiş 2. Basım). Ankara: Nobel Akademik Yayıncilik.

Aydın, R. (1999). Türk basınında öğretmen sorunları (1940-1955 yılları arası). Yayımlanmamış yüksek lisans tezi, Ankara Üniversitesi Sosyal Bilimler Enstitüsü.

Aydın, R. (2008). Türkiye'de eğitimle ilgili yapılan bilimsel toplantılarda ve millî eğitim şûralarında ele alınan öğretmen sorunları ile Millî Eğitim Bakanlığı'nın politika ve uygulamalarının değerlendirilmesi. Yayımlanmamış doktora tezi, Ankara Üniversitesi Eğitim Bilimleri Enstitüsü.

Balc1, A. (2010). Sosyal bilimlerde araştırma yöntem, teknik ve ilkeler. Ankara: Pegem Akademi.

Baysal, Ö., Türkmen, L. ve Yücel, C. (2010). Sınıf öğretmenlerinin mesleki örgütlenmeye yönelik tutumları: Uşak ili örneği. Kuram ve Uygulamada Eğitim Yönetimi, 16(3), 329-352.

Boyacı, H. (1994). Öğretmenlerin mesleki örgütlenmeye ilgilerinin düzeyi ve bu ilgi düzeyinin etkenleri. Yayımlanmamış yüksek lisans tezi, Hacettepe Üniversitesi Sosyal Bilimler Enstitüsü.

Can, N. (2002). Örgütlenme gereksinimi ve önemi. Eğitim ve Bilim, 27(125), 74-78.

Cerev, G. (2014). Geçmişten günümüze öğretmenlerin sendikal örgütlenme mücadelesi. Çankırl Karatekin Üniversitesi Sosyal Bilimler Enstitüsü Dergisi, 4(2), 203-216.

Çalışma ve Sosyal Güvenlik Bakanlığı. (ÇSGB). (2012). 4688 Sayılı Kamu Görevlileri Sendikaları ve Toplu Sözleşme Kanunu. https://www.csgb.gov.tr/media/2058/4688.pdf

Çalışma ve Sosyal Güvenlik Bakanlığı. (ÇSGB). (2017). 4688 Sayılı kamu görevlileri sendikaları ve toplu sözleşme kanunu gereğince kamu görevlileri sendikaları ile konfederasyonların üye sayılarına ilişkin 2017 Temmuz istatistikleri hakkında tebliğ. T.C. Resmi Gazete, 30115, 05 Temmuz 2017.

Demir, E. (2014). Okul yöneticisi ve ögretmenlerin mesleki örgütlenmeye ilişkin tutumlarının incelenmesi (Esenyurt Örneği). Yayımlanmamış yüksek lisans tezi, İstanbul Sabahattin Zaim Üniversitesi Sosyal Bilimler Enstitüsü.

Eraslan, L. (2012a). Türkiye'de eğitim sendikacılığının tarihsel perspektifi ve günümüz eğitim sendikacılığının değerlendirilmesi. Muğla Üniversitesi Sosyal Bilimler Enstitüsü Dergisi, 28, 1-16. 
Eraslan, L. (2012b). Günümüz öğretmen sendikacılığının değerlendirilmesi, 21. yy. 'da Eğitim ve Toplum, Eğitim Bilimleri ve Sosyal Araştırmalar Dergisi, 1(1), 59-72.

Gül, M. H. (2007). Eğitim çalışanlarının eğitim sendikalarına bakışı, beklentileri ve sendikaların eğitim çalışanlarına yönelik faaliyetleri ve beklentileri. Yayımlanmamış yüksek lisans tezi, Yeditepe Üniversitesi Sosyal Bilimler Enstitüsü.

Güvenç, S. (2008). Türkiye'de öğretmen sendikacılığı ve İLK-SEN. Eğitim Bilim Toplum Dergisi, 5(22), 167-187.

Kamu Görevlileri Sendikaları Kanununda Değiş̧iklik Yapılmasına Dair Kanun. (2012). T.C. Resmi Gazete, 28261, 04 Nisan 2012

Kara, M. (2016). Öğretmenlerin sendikalara üye olmama nedenleri ve sendikalardan beklentileri. Akademik Sosyal Araştırmalar Dergisi, 22, 423-440.

Karasar, N. (2012). Bilimsel araştırma yöntemi, kavramlar, ilkeler, teknikler (19. bask1). Ankara: Nobel Yayıncılık.

Karataş, S. (2015). Mesleki örgütlenmeler hakkında eğitim yöneticileri ve öğretmen görüşleri. Eğitim ve Insani Bilimler Dergisi: Teori ve Uygulama, 11, 3-22.

Katkat, D. ve Mızrak, O. (2003). Öğretmen adaylarının pedagojik eğitimlerinin problem çözme becerilerine etkisi. Milli Eğitim Dergisi, 158, 74-82.

Keskinkılıç, K. (2007). Yönetim ve okul yönetimi ile ilgili temel kavramlar. K. Keskinkılıç (Ed.). Türk eğitim sistemi ve okul yönetimi (s.1-26). Ankara: Pegem Akademi Yay.

Kul, S. (2014). Istatistik sonuçlarının yorumu: p değeri ve güven aralı̆̆ nedir? https://www.toraks.org.tr/site/sf/books/pre_migration/c19fa28083ae026a97e3878c26e1b03eaacfd74d114c8d66f832d8d806c56307.pdf

Özdemir, S. (2002). Eğitimde örgütsel yenileşme. Ankara: PegemA Yayıncılık.

Strauss, A. ve Corbin, J. (1997). Grounded theory in practice. Thousand Oaks, CA:Sage.

Tanrı̈ğen, A. (2009). Bilimsel araştırma yöntemleri. Ankara: Anı Yayıncılık.

Taşdan, M. (2013). Eğitim işkolundaki sendikalara ilişkin öğretmen görüşleri; Nitel bir araştırma. Erzincan Üniversitesi Eğitim Fakültesi Dergisi, 15(1), 231-265.

Tezcan, M. (1988). Eğitim sosyolojisi. Ankara: Bilim Yayınları.

Tok, T. N. (1996). Okul yöneticileri ve ögretmenlerin mesleki örgütlenmeye ilişkin görüşleri. Yayımlanmamış yüksek lisans tezi, Hacettepe Üniversitesi Sosyal Bilimler Enstitüsü.

Tortop, N. (2005). Kamu personel yönetimi insan kaynaklarl yönetimi. Ankara: Yarg1 Yayınevi.

Ulutaş, A. ve Sönmez, İ. (2011). Ĕgitimci kadınların sendikal örgütlenme eğilimleri ve sendikal sürece katılım düzeyleri üzerine bir inceleme: (Eskişehir Örneği). Ankara: TÜBİTAK.

Yalçın, A. (2018). Ĕgitim yöneticilerinin demografik özellikleri ile sendikal bağlllıkları arasındaki ilişki (İstanbul Örneği). Yayımlanmamış yüksek lisans tezi, Maltepe Üniversitesi Sosyal Bilimler Enstitüsü.

Yıldırım, A. ve Şimşek, H. (2011). Sosyal bilimlerde nitel araştırma yöntemleri. Ankara: Seçkin Yayıncılık.

Yıldız, G. B. (2015). Kamu işveren sendikalarının alt işverenlerce yetkilendirilmesine ilişkin yasal düzenlemenin değerlendirilmesi. Sicil İş Hukuku Dergisi, 34, 89102. 